\title{
Examination on Perceptions of "Book" Concepts on Teacher Candidates of Turkish and Social Sciences Education
}

\author{
Nevin AKKAYA*a ${ }^{*}$ Eylem Ezgi ÖZDEMİR ${ }^{\mathrm{b}}$, Serdar AKBULUT $^{\mathrm{c}}$
}

\begin{tabular}{l} 
Article Info \\
\hline DOI: $10.14686 /$ buefad.374138 \\
\hline Article History: \\
Received $\quad 03.01 .2018$ \\
Revised $\quad 17.01 .2018$ \\
Accepted $\quad 02.02 .2018$ \\
\hline Keywords: \\
Teacher candidates, \\
Book, \\
Metaphor. \\
\hline Article Type: \\
Research Article \\
\hline
\end{tabular}

\begin{abstract}
The purpose of this study is to determine the perceptions of teacher candidates of Turkish and Social Sciences Education on the concept of "book" through metaphors. The study group consists of 330 students who study in the first and last classes in the second semester of 2016-2017 academic year. The data were obtained through the forms in which the personal information was included and the completed form was given "book for me ... because ...". The 330 data obtained were analyzed by content analysis technique via Nvivo 11 PLUS program and 9 metaphors determined to be weak structure were extracted. The remaining 321 metaphors were compiled to form a metaphor list, grouped by themes and 13 conceptual categories were created. According to the metaphors in these 13 conceptual categories; journey (111), source of information and entertainment (65), friend (44), treasure (22), awareness (22), nature (17), object (11), requirement (11), life (7), insignificant (4), feeling (3), purpose (2) and miracle (2).
\end{abstract}

\section{Türkçe ve Sosyal Bilimler Eğitimi Bölümündeki Öğretmen Adaylarının "Kitap" Kavramı Üzerine Algılarının İncelenmesi}

\begin{tabular}{|c|c|}
\hline \multicolumn{2}{|c|}{ Makale Bilgisi } \\
\hline \multicolumn{2}{|c|}{ DOI: $10.14686 /$ buefad. 374138} \\
\hline \multicolumn{2}{|c|}{ Makale Geçmişi: } \\
\hline $\begin{array}{l}\text { Geliş } \\
\text { Düzeltme } \\
\text { Kabul }\end{array}$ & $\begin{array}{l}03.01 .2018 \\
17.01 .2018 \\
02.02 .2018\end{array}$ \\
\hline \multicolumn{2}{|c|}{$\begin{array}{l}\text { Anahtar Kelimeler: } \\
\text { Öğretmen adayları, } \\
\text { Kitap, } \\
\text { Metafor. }\end{array}$} \\
\hline \multicolumn{2}{|c|}{$\begin{array}{l}\text { Makale Türü: } \\
\text { Araştırma Makalesi }\end{array}$} \\
\hline
\end{tabular}

\section{$\ddot{O} \mathbf{z}$}

Bu çalışmanın amacı Türkçe ve Sosyal Bilimler Eğitimi bölümündeki öğretmen adaylarının "kitap" kavramı üzerine algılarını metaforlar yoluyla belirlemektir. Çalışma grubunu, 2016-2017 eğitim-öğretim yılı ikinci yarıyılında ilk ve son sınıflarında okuyan 330 öğrenci oluşturmaktadır. Veriler, kişisel bilgilerin yer aldığ ve öğrencilerin "benim için kitap... çünkü..."şeklinde verilen ifadeyi tamamladıkları formlar aracılığıyla elde edilmiştir. Elde edilen 330 verinin Nvivo 11 PLUS programı ile içerik analizi yapılmıştır ve zayıf yapıda olduğu düşünülen 9 metafor çıkarılmıştır. Ayıklama sonucunda kalan 321 metafor ile bir metafor listesi oluşturulmuş, temalar aracılığ ile gruplandırılmış 13 kavramsal kategori oluşturulmuştur. Oluşturulan bu 13 kavramsal kategoride yer alan metaforlar; yolculuk (111), bilgi ve eğlence kaynağ (65), dost (44), hazine (22), farkındalık oluşturma (22), doğa (17), nesne (11), gereksinim (11), hayat (7), önemsiz (4), duygu (3), amaç (2), mucize (2) şeklindedir.

\footnotetext{
*Corresponding Author: nevin.akkaya@ deu.edu.tr.

aAssoc. Prof. Dr., Dokuz Eylül University, İzmir/Turkey. http://orcid.org/0000-0001-7222-4562

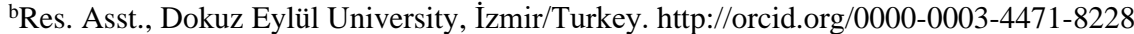

'Res. Asst., Akdeniz University, Antalya/Turkey. http://orcid.org/0000-0002-5809-1481
} 


\section{Introduction}

Reading is a lifelong process that develops the inner world of the individual and offers him the opportunity to discover and learn new information. The tool that the individual often uses throughout this process is undoubtedly the books. One of the main objectives of contemporary education systems is to give individuals reading habits and book love. Because constructivist education is aimed to train the individual by being equipped with the competencies that are at the centre of the learning environment and that actively process, read, listen and follow the information in the learning process and pass them through the mental filters.

In order for teachers to trust future generations to be able to educate individuals who have a habit of reading, they must first have their reading habits and must display a positive attitude toward the "book". For this reason, it is important to determine what kind of perceptions the teachers of tomorrow have against the concept of "book". In this way, metaphors are used to develop interpretations through various simulations and definitions.

Metaphors put forward proposals for another way of looking at things and of grasping inchoate intimations of possibilities. They help us to strive better towards grasping the visions and truths and attempting to share in them (Aspin, 1984:23). Lakoff and Johnson (2005: 27) suggest that metaphors are used extensively in everyday life, and that they have an important influence not just on thinking and acting but also on the basis that our conceptual system is metaphorically. For this reason, metaphors that are effective in visualizing and making sense of the external world are often a source of bedside material for education and training purposes. In national and international literature, metaphor studies are frequently used to determine what kind of perception they develop and what kind of simulations they use while creating their own thought (Alacapınar, 2011; Aydın and Sulak 2015; Bektaş and et.al, 2014; Cerit, 2006; Çelikkaya and Seyhan, 2017; Döş, 2010; Ekici and et.al., 2017; Güneyli and Akıntuğ, 2012; Haggis, 2004; Jensen, 2006; Magalhães and Stoer, 2007; Low and et.al., 2008; Ocak and Gündüz, 2006; Patchen and Crawford, 2011; Saban and et.al., 2006; Saban, 2009; Soysal and Afacan, 2012).

Metaphors developed through various simulations and descriptions have provided information on how teachers are involved in the world of thought. In this way, the purpose of this study is to determine the perceptions of teacher candidates of Turkish and Social Sciences Education on the concept of "book" through metaphors. It is thought that the results obtained will be a guide to educators and families who will be working to educate individuals who gain a habit of reading in the future in our country and exhibit a positive attitude to the book.

\section{Research Hypotheses}

The main purpose of this study is to determine the perceptions of teacher candidates of Turkish and Social Sciences Education on the concept of "book" through metaphors.

The appropriate sub-problems are determined as follows:

- How are the perceptions of the teacher candidates participating in the study on the concept of "book"?

- How are the perceptions of teacher candidates in different departments on the concept of "book"?

- How are the perceptions of teacher candidates at different grade levels on the concept of "book"?

- How are the perceptions of the "gender" teacher candidates on the concept of "book"?

\section{Method}

In this study case studies are used. The case study focuses on phenomena that we are aware of but do not have an in-depth and detailed understanding. In the world we live in, phenomena can emerge in various forms, such as events, experiences, perceptions, orientations, concepts and situations (Yıldırım and Şimşek, 2008: 72). 


\section{Participants}

The study group consists of 330 students who study in the first and last classes of Turkish and Social Sciences Education departments in the second semester of 2016-2017 academic year. Of these, teacher candidates in 140 are Turkish teaching, 64 are Social Informations teaching, 35 are History teaching, 38 are Geography teaching and 53 are Turkish language and literature teaching. Details of the study group are given in Table 1 .

Table 1. Distribution of Working Group by Department, Class and Gender

\begin{tabular}{|c|c|c|}
\hline Sub-dimensions & & $\mathbf{N}$ \\
\hline \multicolumn{3}{|l|}{ Class } \\
\hline & 4.Grade & 185 \\
\hline & 1.Grade & 145 \\
\hline \multirow[t]{3}{*}{ Gender } & Female & 184 \\
\hline & Male & 146 \\
\hline & Turkish & 140 \\
\hline \multirow[t]{4}{*}{ Department } & Social Informations & 64 \\
\hline & Turkish Language and Literature & 53 \\
\hline & Geography & 38 \\
\hline & History & 35 \\
\hline Total & & 330 \\
\hline
\end{tabular}

\section{Data Collection Tools and Analysis of Data}

The data were obtained through the forms in which the personal information was included in the first part and the completed form was given in the second part "book for me ... because ...". The teacher candidates are asked to identify the reason for choosing a concept that can help to recall or express the concept of "book".

The 330 data obtained were analysed by content analysis technique via Nvivo 11 PLUS program and 9 metaphors determined to be weak structure were extracted without working. The remaining 321 metaphors were compiled to form a metaphor list, grouped by various conceptual themes, and 13 conceptual categories were created. As a theme, similar metaphors are grouped under the same headings and transformed into frequency tables.

\section{Findings}

The findings obtained in the study are presented according to the sub-problems.

\section{Examination on the Perceptions of Teacher Candidates on the "Book" Concepts}

The distribution of the findings obtained by means of Nvivo 11 Plus belonging to the theme created by perceptions on the concept of "book" of teacher candidates participating in the study is given in Figure 1. 


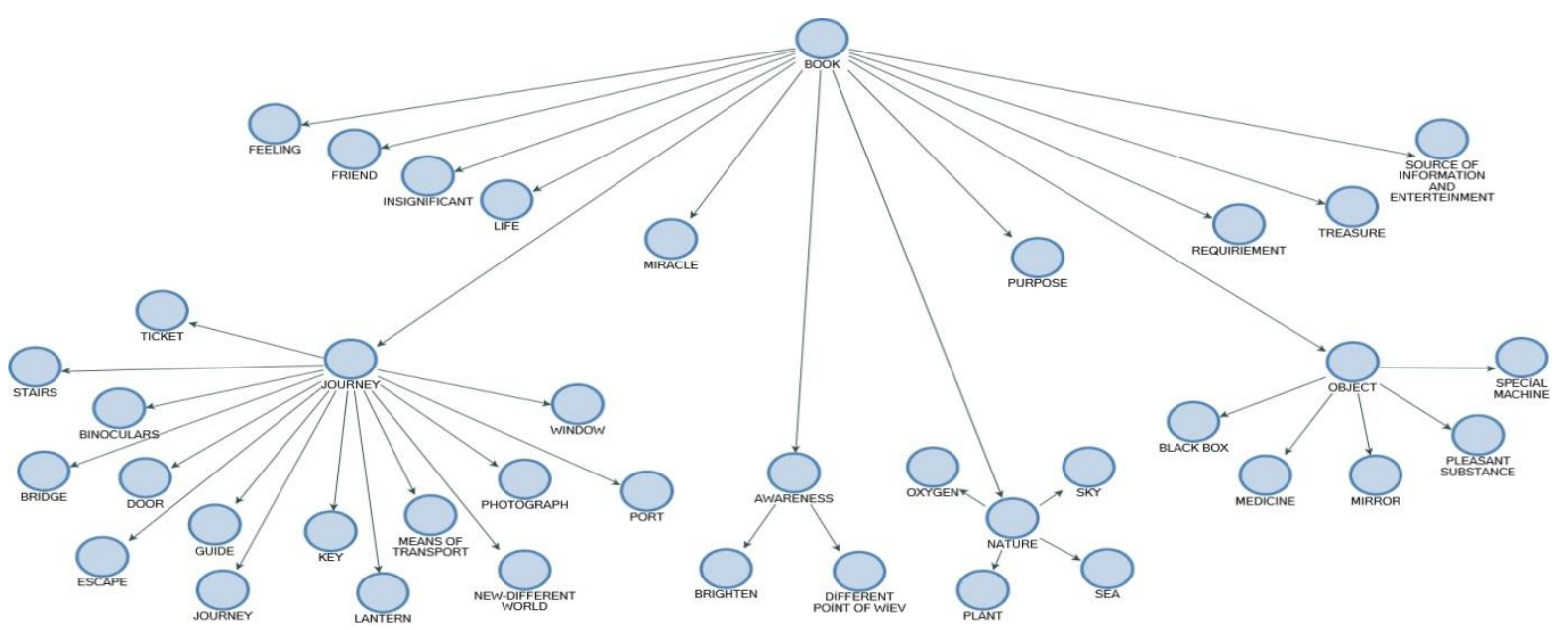

Figure 1. The Distribution of the Themes Formed by the Perceptions of the "book" Concept of the Teacher Candidates

In Figure 1, 13 main themes were formed perceptions on the concept of "book" of teacher candidates participating in the study. These main themes are in the form of journey, source of information and entertainment, friend, awareness, nature, object, requirement, life, insignificant, feeling, treasure, purpose and miracle. There are some main themes underneath, while some main themes stand alone. The baby themes are called branches under the main themes. The frequency values of the main theme and child theme are shown in Table 2 in detail.

Table 2. Frequency Values of the Themes of Metaphors which Constituted by the Teacher Candidates

\begin{tabular}{llc}
\hline Themes & & Frequency \\
\hline & Purpose & 2 \\
Source of information and entertainment & Plant & 65 \\
Nature & Sea & 4 \\
& & 3 \\
& Sky & 8 \\
& Oxygen & 2 \\
Friend & Total & 17 \\
Feeling & & 44 \\
& & 3 \\
Awareness & Brighten & 4 \\
& Different point of view & 18 \\
Requirement & Total & 22 \\
Life & & 11 \\
Treasure & Mirror & 7 \\
Mbjects & & 22
\end{tabular}




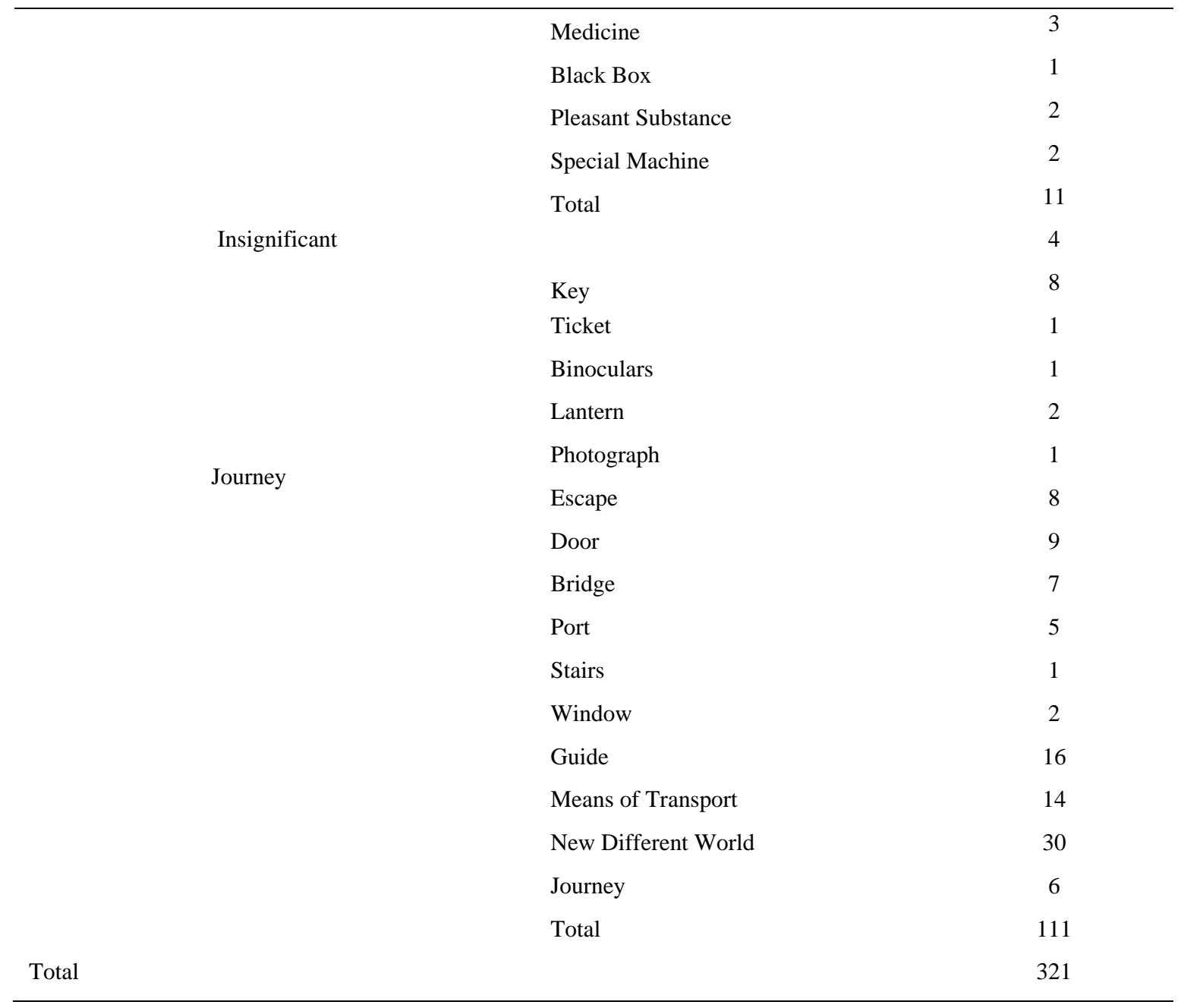

According to Table 2, 330 teacher candidates in the working group have developed 321 metaphors on the concept of the book. A total of 13 conceptual categories were created from 321 metaphors. According to the metaphor numbers in these 13 conceptual categories; journey (111), source of information and entertainment (65), friend (44), treasure (22), awareness (22), nature (17), object (11), requirement (11), life (7), insignificant (4), feeling (3), purpose (2) and miracle (2).

\section{Examination on the Perceptions of Teacher Candidates on the "Book" Concepts in Different Departments}

The distribution of teacher candidates in different departments according to their perceptions and generated themes on the concept of "book" is given in Table 3. 
Table 3. Perceptions of Teacher Candidates on the "Book" Concepts in Different Departments

\begin{tabular}{|c|c|c|c|c|c|c|}
\hline \multicolumn{2}{|c|}{ Themes\Departments } & Turkish & $\begin{array}{l}\text { Turkish } \\
\text { Language and } \\
\text { Department }\end{array}$ & $\begin{array}{l}\text { Social } \\
\text { Informations }\end{array}$ & Geography & History \\
\hline \multicolumn{2}{|l|}{ Purpose } & 2 & 0 & 0 & 0 & 0 \\
\hline \multicolumn{2}{|c|}{$\begin{array}{l}\text { Source of Information and } \\
\text { Entertainment }\end{array}$} & 17 & 7 & 15 & 13 & 13 \\
\hline \multirow{5}{*}{ Nature } & Plant & 1 & 2 & 1 & 0 & 0 \\
\hline & Sea & 2 & 0 & 0 & 0 & 1 \\
\hline & Sky & 5 & 1 & 2 & 0 & 0 \\
\hline & Oxygen & 1 & 0 & 1 & 0 & 0 \\
\hline & Total & 9 & 3 & 4 & 0 & 1 \\
\hline \multicolumn{2}{|l|}{ Friend } & 37 & 9 & 5 & 9 & 4 \\
\hline \multicolumn{2}{|l|}{ Feeling } & 3 & 0 & 0 & 0 & 0 \\
\hline \multirow{3}{*}{ Awareness } & Brighten & 2 & 0 & 1 & 0 & 1 \\
\hline & $\begin{array}{l}\text { Different Point of } \\
\text { View }\end{array}$ & 8 & 0 & 6 & 3 & 1 \\
\hline & Total & 10 & 0 & 7 & 3 & 2 \\
\hline \multicolumn{2}{|l|}{ Requirement } & 7 & 2 & 1 & 1 & 0 \\
\hline \multicolumn{2}{|l|}{ Life } & 2 & 2 & 3 & 0 & 0 \\
\hline \multicolumn{2}{|l|}{ Treasure } & 12 & 3 & 2 & 2 & 3 \\
\hline \multicolumn{2}{|l|}{ Miracle } & 2 & 0 & 0 & 0 & 0 \\
\hline \multirow{6}{*}{ Object } & Mirror & 3 & 0 & 0 & 0 & 0 \\
\hline & Medicine & 2 & 1 & 0 & 0 & 0 \\
\hline & Black Box & 1 & 0 & 0 & 0 & 0 \\
\hline & $\begin{array}{l}\text { Pleasant } \\
\text { Substance }\end{array}$ & 0 & 2 & 0 & 0 & 0 \\
\hline & Special Machine & 2 & 0 & 0 & 0 & 0 \\
\hline & Total & 8 & 3 & 0 & 0 & 0 \\
\hline \multicolumn{2}{|l|}{ Insignificant } & 1 & 1 & 1 & 1 & 0 \\
\hline \multirow{16}{*}{ Journey } & Key & 4 & 2 & 1 & 0 & 1 \\
\hline & Ticket & 1 & 0 & 0 & 0 & 0 \\
\hline & Binoculars & 1 & 0 & 0 & 0 & 0 \\
\hline & Lantern & 2 & 0 & 0 & 0 & 0 \\
\hline & Photograph & 1 & 0 & 0 & 0 & 0 \\
\hline & Escape & 5 & 2 & 1 & 0 & 0 \\
\hline & Door & 4 & 2 & 1 & 1 & 1 \\
\hline & Bridge & 2 & 1 & 0 & 0 & 4 \\
\hline & Port & 1 & 2 & 1 & 1 & 0 \\
\hline & Stairs & 0 & 0 & 1 & 0 & 0 \\
\hline & Window & 2 & 0 & 0 & 0 & 0 \\
\hline & Guide & 7 & 2 & 4 & 3 & 0 \\
\hline & $\begin{array}{l}\text { Means Of } \\
\text { Transport }\end{array}$ & 9 & 4 & 1 & 0 & 0 \\
\hline & $\begin{array}{l}\text { New Different } \\
\text { World }\end{array}$ & 11 & 6 & 8 & 2 & 3 \\
\hline & Journey & 1 & 2 & 0 & 2 & 1 \\
\hline & Total & 51 & 23 & 18 & 9 & 10 \\
\hline
\end{tabular}


Table 3 shows the main themes and subcategories analyzed for the metaphors of Turkish teaching, Turkish language and literature teaching, social informations, geography and history. These categories are detailed in Chart 1.

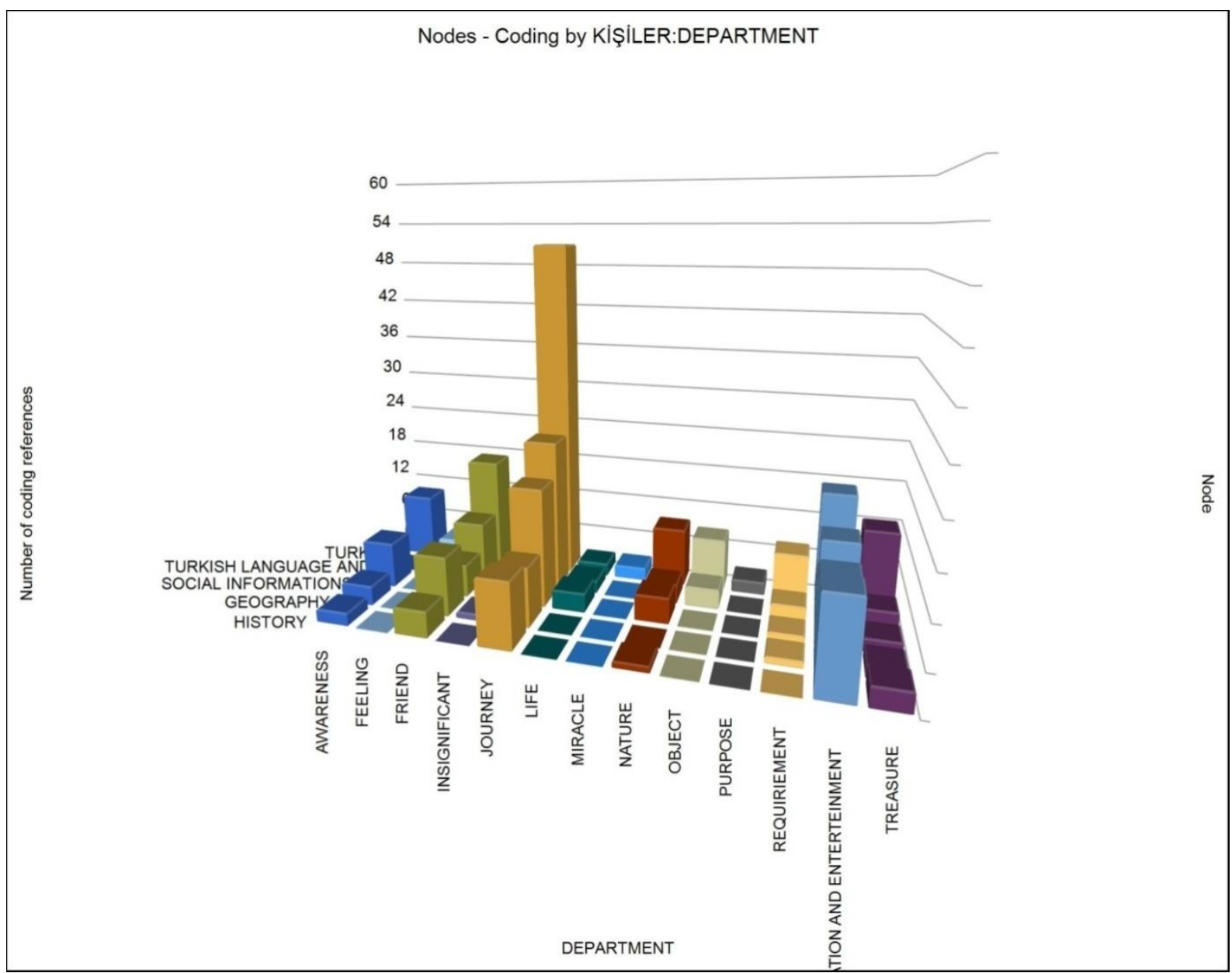

Chart 1. Perceptions of Teacher Candidates in Different Departments on the Concept of "Book"

When Chart 1 is examined, it is seen that the metaphors created about the book have 13 different themes and distribution in different departments. According to the metaphor numbers in the conceptual categories; in Turkish teaching department, journey (51), friend (37), source of information and entertainment (17), treasure (12), awareness (10), nature (9), object (8), requirement (7), feeling (3), life (2), purpose (2), miracle (2) and insignificant (1). In each sub-theme, a metaphor was found to be absolutely involved and it was determined that the metaphor was created in the sub-themes mostly in terms of "journey".

According to the metaphor numbers in the conceptual categories; in Turkish language and literature teaching department, journey (23), friend (9), source of information and entertainment (7), treasure (3), nature (3), object (3), requirement (2), life (2), insignificant (1). There was no metaphor in the themes of feeling, miracle and awareness. According to the metaphor numbers in the conceptual categories; in social informations teaching department, journey (18), source of information and entertainment (7), awareness (7), friend (5), nature (5), life (3), treasure (2), insignificant (1) and requirement (1). There was no metaphor in the themes of feeling, object, purpose and miracle. 
According to the metaphor numbers in the conceptual categories; in Geography teaching department, source of information and entertainment (13), journey (9), friend (9), awareness (3), requirement (1), insignificant (1). There was no metaphor in the themes of feeling, purpose, treasure, object, life and nature. According to the metaphor numbers in the conceptual categories; in History teaching department, source of information and entertainment (13), journey (10), friend (4), treasure (3), awareness (2) and nature (1). There was no metaphor in the themes of object, requirement, life, feeling, purpose, miracle and insignificant.

Here are a few examples of the participants' metaphors to be supportive and explanatory:

"Journey" theme:

“yeni bir yola çıkmak gibi” P251, History D.

“yeni bir serüven” P6, History D.

"Source of information and entertainment" theme:

“içinde yeni bilgiler barındıran bir araç”P160, TLL D.

“eğlence aracı” P176, TLL D.

"Friend" theme:

“yalnızlı̆̆ı unutturan bir dost, arkadaş” P139, Turkish D.

“dost, arkadaş” P190, TLL D.

"Insignificant" theme:

“Önemsiz bir araç” P157, TLL D.

“Önemsiz, vazgeçilebilir bir araçtır” P260, Geo. D.

\section{Examination on the Perceptions of Teacher Candidates on the "Book" Concepts in Different Grades}

The distribution of teacher candidates in different classes according to their perceptions and generated themes on the concept of "book" is given in Table 4.

Table 4. Perceptions of Teacher Candidates in Different Grades on "Book" Concept

\begin{tabular}{lccc}
\hline Themes $\backslash$ Classes & & $\mathbf{1}$ & $\mathbf{4 .}$ \\
\hline Purpose & & 0 & 2 \\
Source of Information and Entertainment & Plant & 22 & 43 \\
Nature & Sea & 3 & 1 \\
& Sky & 2 & 1 \\
& Oxygen & 1 & 7 \\
& Total & 0 & 2 \\
Friend & & 6 & 11 \\
Feeling & & 18 & 26 \\
Awareness & Brighten & 1 & 2 \\
& Different Point of Wiev & 6 & 16 \\
\hline
\end{tabular}




\begin{tabular}{|c|c|c|c|}
\hline & Total & 5 & 13 \\
\hline Requirement & & 2 & 9 \\
\hline Life & & 5 & 2 \\
\hline Treasure & & 13 & 9 \\
\hline Miracle & & 0 & 2 \\
\hline \multirow{7}{*}{ Object } & Mirror & 3 & 0 \\
\hline & Medicine & 1 & 2 \\
\hline & Black Box & 1 & 0 \\
\hline & Pleasant Substance & 2 & 0 \\
\hline & Special Machine & 0 & 2 \\
\hline & & 7 & 4 \\
\hline & Total & & \\
\hline \multirow[t]{9}{*}{ Insignificant } & & 4 & 0 \\
\hline & Key & 2 & 6 \\
\hline & Ticket & 1 & 0 \\
\hline & Binoculars & 1 & 0 \\
\hline & Lantern & 2 & 0 \\
\hline & Photograph & 0 & 1 \\
\hline & Escape & 4 & 4 \\
\hline & Door & 2 & 7 \\
\hline & Bridge & 2 & 5 \\
\hline \multirow[t]{8}{*}{ Journey } & Port & 0 & 5 \\
\hline & Stairs & 1 & 0 \\
\hline & Window & 2 & 0 \\
\hline & Guide & 6 & 10 \\
\hline & Means Of Transport & 6 & 8 \\
\hline & New Different World & 18 & 12 \\
\hline & Journey & 5 & 1 \\
\hline & Total & 52 & 59 \\
\hline
\end{tabular}

Table 4 presents the main themes and subcategories analyzed for the metaphors of the first and fourth grade teacher candidates. These categories are detailed in Chart 2. 


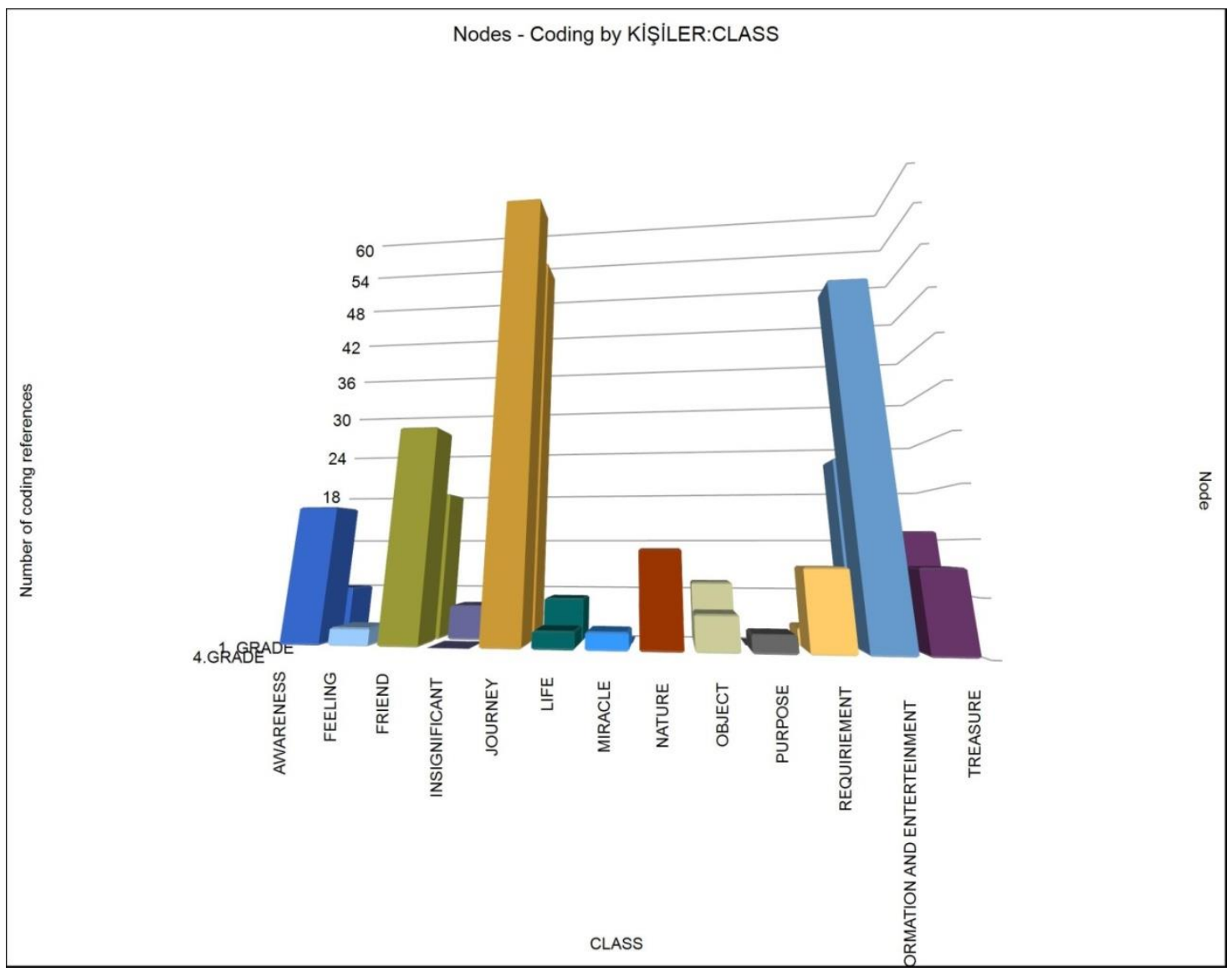

Chart 2. Perceptions of Teacher Candidates in Different Grades on "Book” Concept

When Chart 2 is examined, it is seen that the metaphors created about the book have 13 different themes and distribution in the first and fourth classes. According to the metaphor numbers in the conceptual categories; in first grade, journey (52), source of information and entertainment (22), friend (18), treasure (13), object (7), nature (6), awareness (5), life (5), insignificant (4), requirement (2) and feeling (1). There was no metaphor in the themes of purpose and miracle. According to the metaphor numbers in the conceptual categories; in fourth grade, journey (59), source of information and entertainment (43), friend (26), awareness (13), nature (11), treasure (9), requirement (9), object (4), life (2), feeling (2), purpose (2) and miracle (2). There was no metaphor in the theme of insignificant.

Here are a few examples of the participants' metaphors to be supportive and explanatory:

“Journey" theme:

“sürekli farklı bilgiler katmaya devam eden sonsuzluğa giden bir yolculuğun gemisi” P144, 1. Grade.

“dünyanın en güzel karavanıdır” P101, 4. Grade.

"Source of information and entertainment" theme:

"ruhu dinlendiren bir araç” P136, 4. G.

“eğlenme aracı” P258, 1.G.

10 
"Friend" theme:

“yalnız kaldı̆̆ımızda gizli bir dost” P2, 1. G.

“her zaman yanında olan dost” P323, 4. G.

"Insignificant" theme:

“Önemsiz bir araç” P157, 1. G.

“Önemsiz, vazgeçilebilir bir araçtır” P260, 1. G.

4. Examination on the Perceptions of Teacher Candidates on the "Book" Concepts in Different Gender The distribution of teacher candidates in different gender according to their perceptions and generated themes on the concept of "book" is given in Table 5.

Table 5. Perceptions of Teacher Candidates on the "Book" Concepts in Different Gender

\begin{tabular}{|c|c|c|c|}
\hline \multicolumn{2}{|c|}{ Themes/Gender } & Male & Female \\
\hline \multicolumn{2}{|l|}{ Purpose } & 1 & 1 \\
\hline \multicolumn{2}{|c|}{ Source of Information and Entertainment } & 35 & 30 \\
\hline \multirow{5}{*}{ Nature } & Plant & 4 & 0 \\
\hline & Sea & 1 & 2 \\
\hline & Sky & 4 & 4 \\
\hline & Oxygen & 1 & 1 \\
\hline & Total & 10 & 7 \\
\hline Friend & & 27 & 17 \\
\hline \multirow[t]{2}{*}{ Feeling } & & 1 & 2 \\
\hline & Brighten & 2 & 2 \\
\hline \multirow[t]{2}{*}{ Awerenes } & Different Point of Wiev & 9 & 9 \\
\hline & Total & 11 & 11 \\
\hline \multicolumn{2}{|l|}{ Requirement } & 4 & 7 \\
\hline \multicolumn{2}{|l|}{ Life } & 4 & 3 \\
\hline \multicolumn{2}{|l|}{ Treasure } & 12 & 10 \\
\hline \multicolumn{2}{|l|}{ Miracle } & 2 & 0 \\
\hline \multirow{6}{*}{ Objects } & Mirror & 3 & 0 \\
\hline & Medicine & 2 & 1 \\
\hline & Black Box & 0 & 1 \\
\hline & Pleasant Substance & 0 & 2 \\
\hline & Special Machine & 0 & 2 \\
\hline & Total & 5 & 6 \\
\hline \multicolumn{2}{|l|}{ Insignificant } & 1 & 3 \\
\hline
\end{tabular}




\begin{tabular}{llcc}
\hline & Key & 4 & 4 \\
Ticket & 0 & 1 \\
Binoculars & 1 & 0 \\
Lantern & 1 & 1 \\
Photograph & 1 & 0 \\
Escape & 7 & 1 \\
Dourney & Bridge & 6 & 3 \\
& Port & 1 & 1 \\
Stairs & 4 & 1 \\
Window & 0 & 0 \\
Guide & 2 & 9 \\
Means Of Transport & 7 & 2 \\
New Different World & 12 & 11 \\
Journey & 19 & 2 \\
Total & 4 & 69 \\
\hline
\end{tabular}

Table 5 presents the main themes and subcategories analysed for the metaphors of the male and female teacher candidates. These categories are detailed in Chart 3.

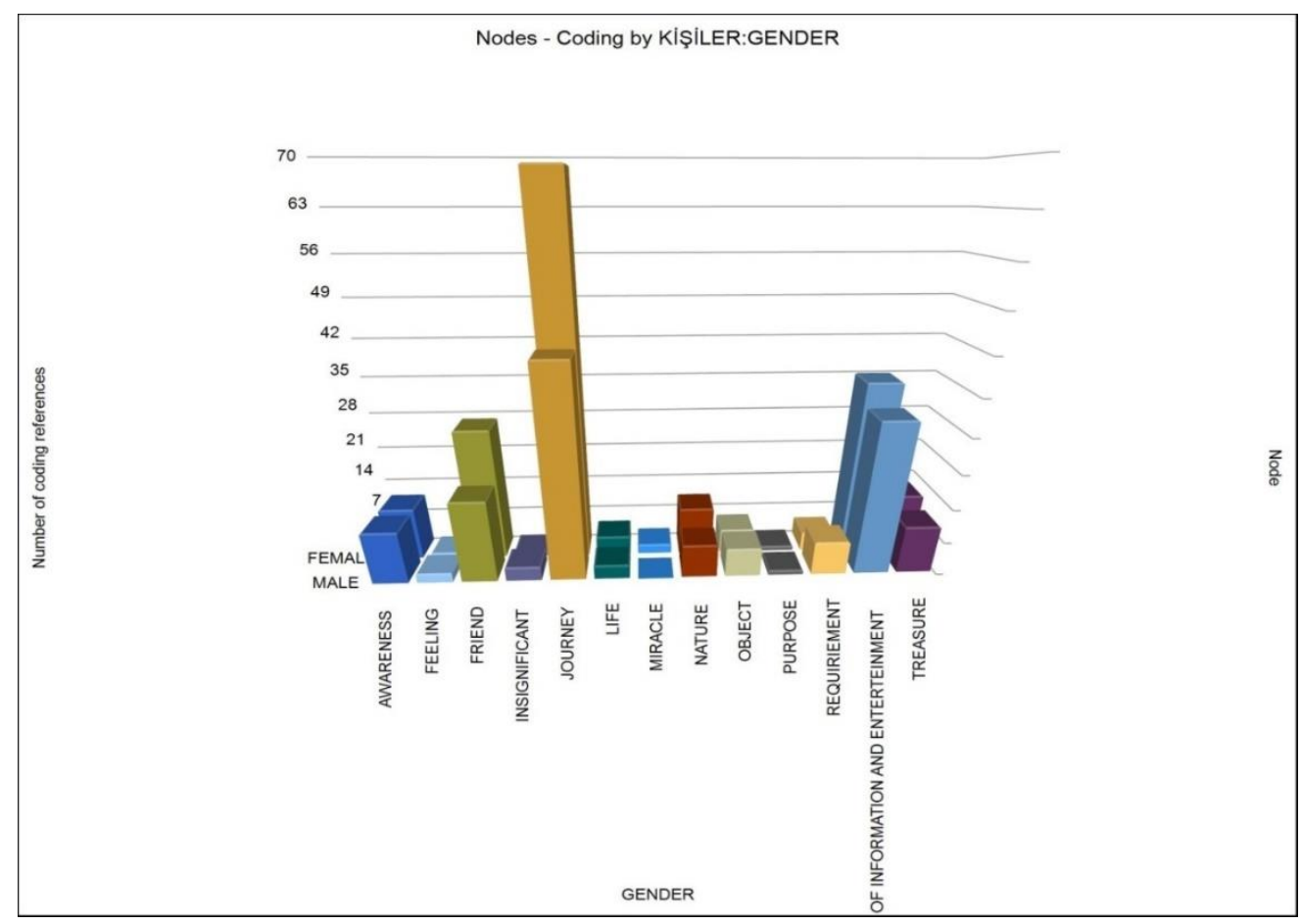

Chart 3. Perceptions of Teacher Candidates on the "Book" Concepts in Different Gender 
When Chart 3 is examined, it is seen that 13 metaphors about book are distributed among female and male teacher candidates. According to the metaphor numbers in the conceptual categories; in female, journey (69), source of information and entertainment (35), friend (27), treasure (12), awareness (11), nature (10), object (5), requirement (4), life (4), miracle (2), insignificant (1), feeling (1) and purpose (1). In male, journey (42), source of information and entertainment (30), friend (17), awareness (11), treasure (10), nature (7), requirement (7), object (6), life (3), insignificant (3), feeling (2) and purpose (1). There was no metaphor in the theme of miracle.

Here are a few examples of the participants' metaphors to be supportive and explanatory:

"Journey" theme:

“yeni bir yola çıkmak gibi” P251, Female.

“yolculuk aracıdır” P14, Female.

"Source of information and entertainment" theme:

“bireyin gelişmesini sağlayan araç” P169, Male.

“güzel ve şahane bir araç”P217, Male.

"Friend" theme:

“arkadaşımdır” P88, Male.

“arkadaş, sırdaş” P118, Female.

"Insignificant" theme:

“cümlelerden ibaret, önemsiz” P21, Male.

“vakit kaybıdır” P42, Male.

\section{Conclusion and Recommendations}

The results of this study, which was conducted in order to determine the perceptions of the teacher candidates in the Turkish and Social Sciences Education department on the concept of "book" through metaphors, were discussed and sorted according to the sub-problems of the study. At the end of the study, 13 sub-themes were formed in the form of a total of 321 metaphors; journey (111), source of information and entertainment (65), friend (44), treasure (22), awareness (22), nature (17), object (11), requirement (11), life (7), insignificant (4), feeling (3), purpose (2) and miracle (2) obtained from the participants.

When the findings are examined, it is seen that teacher candidates use the most "journey" metaphor related to the book. The similarity of the majority of teacher candidates to a journey can be interpreted as a view of the book as new information to be learned and a new world opening. The second most used theme is book as "information and entertainment source". This perception of teacher candidates can be interpreted as the way in which learning styles combine knowledge and entertainment. This perception is also an important result in terms of finding an amusing way to learn and to learn, which an aim is in today's education system.

The third most frequently used theme is "friend". This perception of the teacher candidates is a reflection of the saying "Book is best friend" supported by various words and phrases from the primary school. One of the first metaphors that come to mind when you think of the book is undoubtedly "friend". It has been determined that most of the teacher candidates' in our work regarded the book as a "friend" in a similar way. 
In general, it is seen that 12 themes is positive and a theme is categorized as negative, based on the metaphors created by the teacher candidates. It was seen that 317 of the 321 teacher candidates participating in the study developed a positive metaphor for the book and only 4 developed a negative metaphor by saying "insignificant". This is a sign that teacher candidates' perceptions toward the church are positive.

When analysed by the metaphor developed by the teacher candidates according to the departments, it is seen that teacher candidates in Turkish, Turkish language and literature and social studies teaching department use the metaphor of "journey" at the highest level. In the geography and history teaching departments, "source of information and entertainment" was seen at the highest level.

It is noteworthy that the metaphors "nature" has not been developed in the geography teaching department when the results obtained are considered in more detail. Another outcome is that a student from every department, except the history teaching department, regards the book as "insignificant". It is worrisome that the teacher who will train the individuals who have gained the habit of reading books in the future finds the book "insignificant". However, the low number of people alleviates this concern.

When examined according to the classes in the first class, journey (52), source of information and entertainment (22), friend (18), treasure (13), object (7), nature (6), awareness (5) insignificant(4), requirement(2) and feeling (1). Teacher candidates in the first grade did not create metaphors in the purpose and miracle themes. The metaphors created by the fourth grade teacher candidates are journey (59), source of information and entertainment (43), friend (26), awareness (13), nature (11), treasure (9), life (2), feeling (2), purpose (2) and miracle (2). None of the fourth grade teacher candidates created metaphors in the sense of "insignificant".

It is an important result that those who perceive it as "insignificant" by taking a negative attitude towards the book when compared to the first and fourth classes are included only in the first class. In the education faculties, the methods of gaining and acquiring reading habits are included in the content of almost every course. It is hoped that the final concentration of these finalists will increase the number of candidates who will gain the love of reading the future, and that the teacher candidates will have an effect on the positive attitude towards the book in the coming years.

Metaphor numbers in these 13 themes according to gender variables are shown in female as journey (69), source of information and entertainment (35), friend (27), treasure (12), awareness (11), nature (10), need (4), life (4), miracle (2), insignificant (1), feeling (1) and purpose (1). In male, journey (42), source of information and entertainment (30), friend (17), awareness (11), treasure (10), nature (7), insignificant (3), feeling (2) and purpose (1). Metaphor was not created in the miracle. There was no significant difference between male and female. The most commonly used metaphors are gathered in terms of "journey, source of information and friend".

As a result; perceptions of teacher candidates about book concept; it is essential that the development of the reading habit and love of reading. Because education is a field in which metaphors play an important role both to define the dynamics of educational processes and to clarify and classify the functions of educational actors (Jensen, 2006; Magalhães and Stoer, 2007; Patchen and Crawford, 2011).

Also, as Haggis (2004) states, metaphors can be used to shape thinking. The use of metaphors in educational settings allows us to see learning in different dimensions. For this reason, in the process of teacher education, students can develop their thought world by making activities especially for students to make metaphor in comprehension and narration education courses. This study, limited to teacher candidates who are currently studying in the department of Turkish and social sciences education, in the future can be enriched with teacher candidates in other departments. This work, which has the originality of teacher candidates' metaphor for motion with the concepts of "book", can be rethought on the concepts of "book" by contributing to the text.

\section{Acknowledgments}

This study was supported by the DEU BAP with the name "2017.KB.EGT.002" and the number "201759". 


\title{
Türkçe ve Sosyal Bilimler Eğitimi Bölümündeki Öğretmen Adaylarının “Kitap" Kavramı Üzerine Algılarının İncelenmesi
}

\author{
Giriş
}

Okuma bireyin iç dünyasını geliştiren, ona yeni bilgileri keşfetme ve öğrenme imkânı sunan ve yaşam boyu etkili olan bir süreçtir. Bireyin bu süreç boyunca sıklıkla kullandığı araç ise şüphesiz ki kitaptır. Çağdaş eğitim sistemlerinin temel hedeflerinden biri, bireylere kitap okuma alışkanlığı ve kitap sevgisi kazandırmaktır. Çünkü yapılandırmacı eğitim anlayışında bireyin, öğrenme ortamının merkezinde olan, öğrenme sürecinde bilgileri aktif olarak işleyen, okuduğunu, dinlediğini, izlediğini zihinsel süzgeçlerden geçirerek sentezleyen yeterliliklerle donanarak yetişmesi hedeflenmektedir.

Gelecek nesilleri emanet edeceğimiz öğretmen adaylarının kitap okuma alışkanlığına sahip bireyler yetiştirebilmesi için öncelikle kendilerinin okuma alışkanlığına sahip olması ve kitaba karşı olumlu tutum sergilemesi gerekmektedir. Bu nedenle öğretmen adaylarının "kitap" kavramına karşı algılarının nasıl olduğunu belirlemek, onlara kitap okuma alışkanlığı ve okuma sevgisi kazandırma çalışmaları açısından önemlidir. Bu şekilde çeşitli benzetim ve tanımlamalar aracılığıyla yorumlar geliştirmek için metaforlardan yararlanılmaktadır.

Metaforlar, bir şeylere bakmanın başka bir yolu için öneriler ileri sürerek imgeleri kavramayı sağlar. Gerçeklikleri ve görüşleri daha iyi anlamamıza ve paylaşmamıza yardım eder (Aspin, 1984:23). Lakoff ve Johnson (2005: 27) metaforların günlük yaşamda çok yaygın olarak kullanıldığını, sadece dilde değil düşünce ve harekete geçmede önemli bir etkiye sahip olduklarını ileri sürer ve esas olarak kavramsal sistemimizin metaforik olduğunu vurgular. Bu nedenle dış dünyayı görselleştirmede ve anlamlandırmada etkili olan metaforlar, genelde eğitim ve öğretim amaçlı olarak sıklıkla kullanılabilecek bir başucu kaynağıdır.

Ulusal ve uluslararası alan yazında da bireylerin kendi düşünce sistemlerini oluştururken nasıl bir algı geliştirdikleri ve ne tür benzetimler kullandıklarını belirlemek için sıklıkla metafor çalışmalarından yararlanılmaktadır (Alacapınar, 2011; Aydın ve Sulak 2015; Bektaş ve diğerleri, 2014; Cerit, 2006; Çelikkaya ve Seyhan, 2017; Döş, 2010; Ekici ve diğerleri, 2017; Güneyli ve Akıntuğ, 2012; Haggis, 2004; Jensen, 2006; Magalhães ve Stoer, 2007; Low ve diğerleri, 2008; Ocak ve Gündüz, 2006; Patchen ve Crawford, 2011; Saban ve diğerleri, 2006; Saban, 2009; Soysal ve Afacan, 2012).

Bir kavrama yönelik algıyı belirlerken metaforlar geliştirmenin etkili bir yöntem olduğu düşüncesi ile bu çalışmada Türkçe ve Sosyal Bilimler Eğitimi bölümündeki öğretmen adaylarının "kitap" kavramı üzerine algılarını belirlemek amaçlanmıştır. Çeşitli benzetimler ve tanımlamalar yoluyla geliştirilen metaforlarla öğretmen adaylarının düşünce dünyasında kitapların nasıl yer aldığı hakkında bilgi edinilmiştir. Elde edilen sonuçların, bireylerin kitaba karşı olumlu bir tutum geliştirmelerini sağlamak üzere yapılacak çalışmalara, eğitimcilere ve ailelere yol gösterici olacağı düşünülmektedir.

\section{Yöntem}

Bu bölümde sırasıyla çalışmanın amacı, modeli, çalışma grubu, veri toplama aracı, verilerin toplanması ve son olarak verilerin analizi ile ilgili bilgiler sunulmaktadır.

\section{Çalışmanın Amacı}

Bu çalışmanın amacı Türkçe ve Sosyal Bilimler Eğitimi bölümündeki öğretmen adaylarının "kitap” kavramı üzerine algılarını metaforlar yoluyla belirlemektir. Böylece öğretmen adaylarının kitaba yönelik zihinsel imgelerinin ortaya çıkarılması amaçlanmaktadır. Ortaya çıkan metaforlar ile öğretmen adaylarının kitaba ilişkin algılarının betimlenmesinin kitaba ilişkin farkındalığın gelişmesinde önemli rol oynayacağı düşünülmektedir. Amaca uygun alt problemler şu şekilde belirlenmiştir:

- Çalışmaya katılan öğretmen adaylarının "kitap” kavramı üzerine algıları nasıldır?

- Farklı bölümlerdeki öğretmen adaylarının "kitap” kavramı üzerine algıları nasıldır?

- Farklı sınıf düzeylerindeki öğretmen adaylarının "kitap” kavramı üzerine algıları nasıldır?

- Farklı cinsiyetteki öğretmen adaylarının "kitap” kavramı üzerine algıları nasıldır? 


\section{Çalışmanın Deseni}

Bu çalışmada olgubilim deseni kullanılmıştır. Olgubilim deseni, farkında olduğumuz ancak derinlemesine ve ayrıntılı bir anlayışa sahip olmadığımız olgulara odaklanmaktadır. Olgular yaşadığımız dünyada olaylar, deneyimler, algılar, yönelimler, kavramlar ve durumlar gibi çeşitli biçimlerde karşımıza çıkabilmektedir (Yıldırım ve Şimşek, 2008: 72).

\section{Çalışma Grubu}

Çalışma grubu 2016-2017 eğitim-öğretim yılı ikinci yarıyılında Türkçe ve Sosyal Bilimler Eğitimi bölümlerinin ilk ve son sınıflarında okuyan 330 öğretmen adayından oluşmaktadır. Bunlardan 140'1 Türkçe öğretmenliği, 64’ü sosyal bilgiler öğretmenliği, 53’ü ise Türk dili ve edebiyatı öğretmenliği, 38'i coğrafya öğretmenliği, 35 'i tarih öğretmenliği bölümündeki öğretmen adaylarıdır. Çalışma grubuna ait bilgilerin detaylarına Tablo 1'de yer verilmiştir.

Tablo 1. Çalışma Grubunun Sınıf, Cinsiyet ve Bölüme Göre Dağılımı

\begin{tabular}{llc}
\hline Bilgiler & & Sayı \\
\hline Sinıf & 4.Sinıf & 185 \\
& 1.Sinıf & 145 \\
Cinsiyet & Kadın & 184 \\
& Erkek & 146 \\
& Türkçe & \\
Bölüm & Sosyal Bilgiler & 140 \\
& Türk Dili ve Edebiyatı & 64 \\
& Coğrafya & 53 \\
Tarih & 38 \\
Toplam & & 35 \\
& & 330
\end{tabular}

\section{Veri Toplama Aracı}

Araştırmanın verilerini toplamak için boşluk doldurmayı gerektiren ve iki bölümden oluşan bir form kullanılmıştır. Birinci bölümde öğretmen adaylarının kişisel bilgileri yer alırken ikinci bölümde "benim için kitap... çünkü..." şeklinde verilen ifadenin tamamlanması sağlanmıştır. Öğretmen adaylarından "kitap" kavramını çağrıştırabilecek ya da ifade edebilmelerine yardımcı olabilecek bir kavramı nedeni ile birlikte yazmaları istenmiştir.

\section{Verilerin Analizi}

Araştırma sonunda, öğretmen adayları tarafından belirlen metaforlar benzetme yönlerinden hareket ederek Nvivo 11 PLUS programı aracılığı ile içerik analizi yoluyla incelenmiştir. Tema olarak birbirine benzer metaforlar aynı başlıklar altında toplanarak frekans değerleri ile tablolara dönüştürülmüştür.

\section{Bulgular ve Yorumlar}

Çalışmada elde edilen bulgular alt amaçlara göre sunulmuştur.

\section{1. Çalışmaya Katılan Öğretmen Adaylarının “Kitap” Kavramı Üzerine Algılarının İncelenmesi}

Çalışmaya katılan öğretmen adaylarının "kitap” kavramı üzerine algıları ile oluşturulan temalara ait Nvivo 11 Plus aracılığıyla elde edilen bulguların dağılımı Şekil 1'de verilmiştir. 


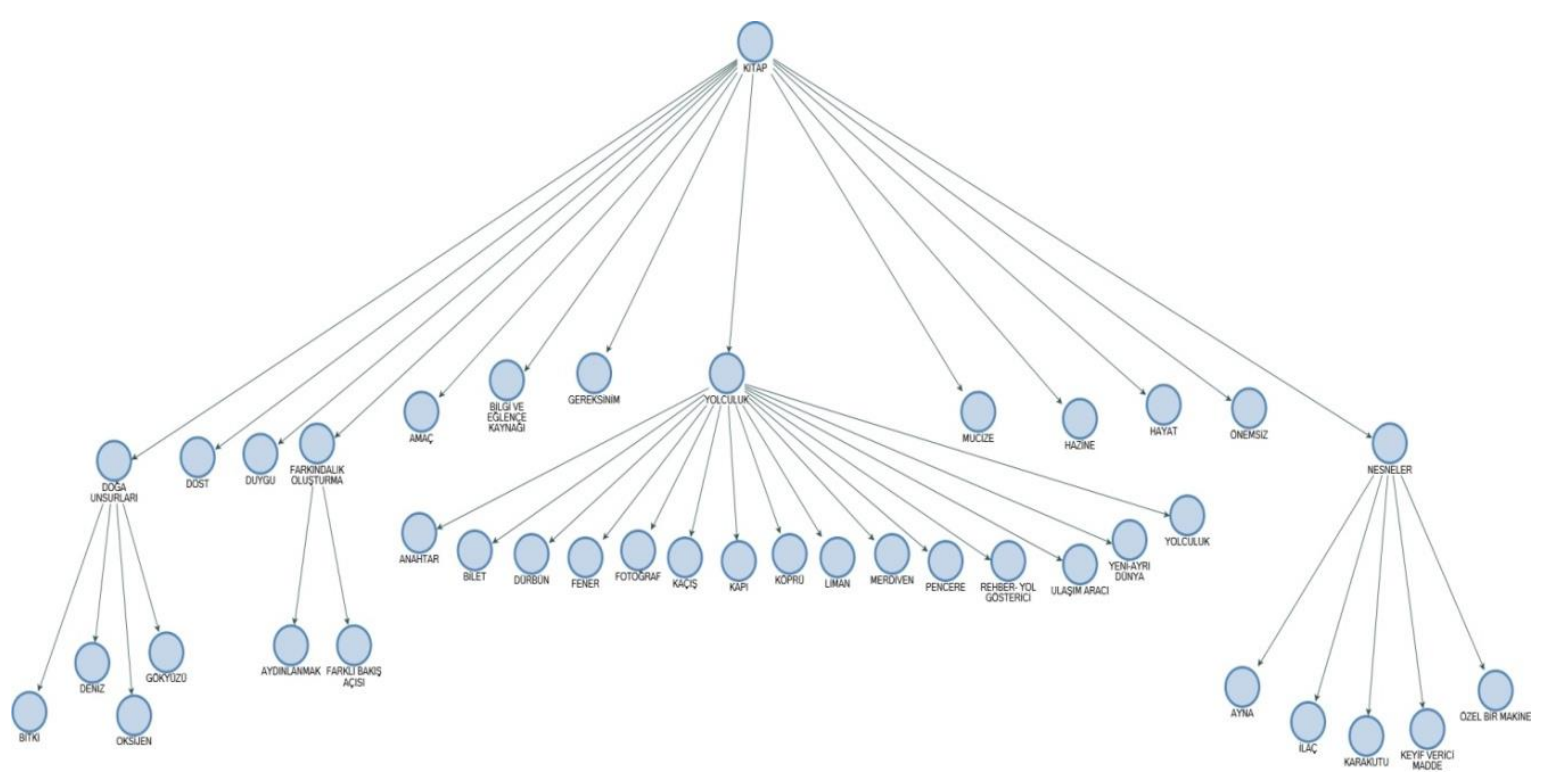

Şekil 1'e göreçalışmaya katılan öğretmen adaylarının "kitap" kavramı üzerine algıları ile 13 ana tema oluşturulmuştur. Bu ana temalar; yolculuk, bilgi ve eğlence kaynağı, dost, farkındalık oluşturma, doğa, nesne, gereksinim, hayat, önemsiz, duygu, amaç ve mucize şeklindedir. Bazı ana temaların altında yavru temalar yer alırken bazı ana temalar tek başlarına yer almaktadır. Yavru temalar, ana temaların altında dallar olarak gösterilmiştir. Oluşturulan ana temalara ve yavru temalara ait frekans değerleri detaylı olarak Tablo 2'de verilmiştir.

Tablo 2. Çalışma Grubunda Yer Alan Öğretmen Adaylarının Oluşturdukları Metaforların Temalara Göre Dağılımına Ait Frekans Değerleri

\begin{tabular}{|c|c|c|c|}
\hline \multicolumn{3}{|l|}{ Temalar } & \multirow{2}{*}{$\begin{array}{c}\text { Frekans } \\
2\end{array}$} \\
\hline \multirow{14}{*}{ 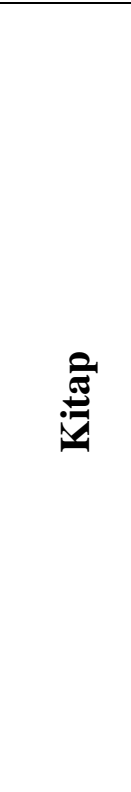 } & Amaç & & \\
\hline & \multicolumn{2}{|c|}{ Bilgi ve Eğlence Kaynağ 1} & 65 \\
\hline & \multirow[t]{5}{*}{ Doğa } & Bitki & 4 \\
\hline & & Deniz & 3 \\
\hline & & Gökyüzü & 8 \\
\hline & & Oksijen & 2 \\
\hline & & Toplam & 17 \\
\hline & Arkadaş & & 44 \\
\hline & \multicolumn{2}{|l|}{ Duygu } & 3 \\
\hline & \multirow{3}{*}{ Farkındalık Oluşturma } & Aydınlanmak & 4 \\
\hline & & Farklı Bakış Açısı & 18 \\
\hline & & Toplam & 22 \\
\hline & \multicolumn{2}{|l|}{ Gereksinim } & 11 \\
\hline & \multicolumn{2}{|l|}{ Yaşam } & 7 \\
\hline
\end{tabular}




\begin{tabular}{|c|c|c|c|}
\hline & Hazine & & 22 \\
\hline & Yaşam & & 2 \\
\hline & & Ayna & 3 \\
\hline & & Ilaç & 3 \\
\hline & Nesneler & Karakutu & 1 \\
\hline & & Keyif Verici Madde & 2 \\
\hline & & Özel Makine & 2 \\
\hline & & Toplam & 11 \\
\hline & Önemsiz & & 4 \\
\hline & & Anahtar & 8 \\
\hline & & Bilet & 1 \\
\hline & & Dürbün & 1 \\
\hline & & Fener & 2 \\
\hline & Yolculuk & Fotoğraf & 1 \\
\hline & 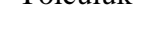 & Kaçış & 8 \\
\hline & & Kap1 & 9 \\
\hline & & Köprü & 7 \\
\hline & & Liman & 5 \\
\hline & & Merdiven & 1 \\
\hline & & Pencere & 2 \\
\hline & & Rehber & 16 \\
\hline & & Ulaşım Aracı & 14 \\
\hline & & Yeni Farklı Dünya & 30 \\
\hline & & Yolculuk & 6 \\
\hline & & Toplam & 111 \\
\hline Toplam & & & 321 \\
\hline
\end{tabular}

Tablo 2'ye göre çalışma grubunda yer alan 330 öğretmen adayının kitap kavramına ilişkin 321 metafor geliştirdikleri saptanmıştır Toplam 321 metafordan 13 kavramsal kategori oluşturulmuştur. Oluşturulan bu 13 kavramsal kategoride yer alan metafor sayılarına göre; yolculuk (111), bilgi ve eğlence kaynağı (65), dost (44), hazine (22), farkındalık oluşturma (22), doğa (17), nesne (11), gereksinim (11), hayat (7), önemsiz (4), duygu (3), amaç (2), mucize (2) şeklinde sıralanmaktadır.

\section{Farkı Bölümlerdeki Öğretmen Adaylarının "Kitap” Kavramı Üzerine Algılarının İncelenmesi}

Farklı bölümlerdeki öğretmen adaylarının "kitap" kavramı üzerine algıları ve oluşturulan temalara göre dağılımı Tablo 3’te verilmiştir. 
Tablo 3. Farklı Bölümlerdeki Öğretmen Adaylarının “Kitap” Kavramı Üzerine Algıları

\begin{tabular}{|c|c|c|c|c|c|c|}
\hline \multicolumn{2}{|c|}{ Temalar\ Bölümler } & Türkçe & $\begin{array}{l}\text { Türk Dili ve } \\
\text { Edbiyatı }\end{array}$ & Sosyal Bilgiler & Coğrafya & Tarih \\
\hline \multicolumn{2}{|l|}{ Amaç } & 2 & 0 & 0 & 0 & 0 \\
\hline \multicolumn{2}{|c|}{ Bilgi ve Eğlence Kaynağ } & 17 & 7 & 15 & 13 & 13 \\
\hline \multirow{5}{*}{ Doğa } & Bitki & 1 & 2 & 1 & 0 & 0 \\
\hline & Deniz & 2 & 0 & 0 & 0 & 1 \\
\hline & Gökyüzü & 5 & 1 & 2 & 0 & 0 \\
\hline & Oksijen & 1 & 0 & 1 & 0 & 0 \\
\hline & Toplam & 9 & 3 & 4 & 0 & 1 \\
\hline \multicolumn{2}{|l|}{ Dost } & 37 & 9 & 5 & 9 & 4 \\
\hline \multicolumn{2}{|l|}{ Duygu } & 3 & 0 & 0 & 0 & 0 \\
\hline \multirow{3}{*}{$\begin{array}{l}\text { Farkındalık } \\
\text { Oluşturma }\end{array}$} & Aydınlanmak & 2 & 0 & 1 & 0 & 1 \\
\hline & $\begin{array}{l}\text { Farklı Bakış } \\
\text { Açısı }\end{array}$ & 8 & 0 & 6 & 3 & 1 \\
\hline & Toplam & 10 & 0 & 7 & 3 & 2 \\
\hline \multicolumn{2}{|l|}{ Gereksinim } & 7 & 2 & 1 & 1 & 0 \\
\hline \multicolumn{2}{|l|}{ Yaşam } & 2 & 2 & 3 & 0 & 0 \\
\hline \multicolumn{2}{|l|}{ Hazine } & 12 & 3 & 2 & 2 & 3 \\
\hline \multicolumn{2}{|l|}{ Mucize } & 2 & 0 & 0 & 0 & 0 \\
\hline & Ayna & 3 & 0 & 0 & 0 & 0 \\
\hline & İlaç & 2 & 1 & 0 & 0 & 0 \\
\hline \multirow[t]{4}{*}{ Nesneler } & Karakutu & 1 & 0 & 0 & 0 & 0 \\
\hline & $\begin{array}{l}\text { Keyif Verici } \\
\text { Madde }\end{array}$ & 0 & 2 & 0 & 0 & 0 \\
\hline & Özel Bir Madde & 2 & 0 & 0 & 0 & 0 \\
\hline & Toplam & 8 & 3 & 0 & 0 & 0 \\
\hline \multicolumn{2}{|l|}{ Önemsiz } & 1 & 1 & 1 & 1 & 0 \\
\hline & Anahtar & 4 & 2 & 1 & 0 & 1 \\
\hline & Bilet & 1 & 0 & 0 & 0 & 0 \\
\hline & Dürbün & 1 & 0 & 0 & 0 & 0 \\
\hline & Fener & 2 & 0 & 0 & 0 & 0 \\
\hline \multirow[t]{12}{*}{ Yolculuk } & Fotoğraf & 1 & 0 & 0 & 0 & 0 \\
\hline & Kaçış & 5 & 2 & 1 & 0 & 0 \\
\hline & Kap1 & 4 & 2 & 1 & 1 & 1 \\
\hline & Köprü & 2 & 1 & 0 & 0 & 4 \\
\hline & Liman & 1 & 2 & 1 & 1 & 0 \\
\hline & Merdiven & 0 & 0 & 1 & 0 & 0 \\
\hline & Pencere & 2 & 0 & 0 & 0 & 0 \\
\hline & Rehber & 7 & 2 & 4 & 3 & 0 \\
\hline & Ulaşım Aracı & 9 & 4 & 1 & 0 & 0 \\
\hline & $\begin{array}{l}\text { Yeni Farklı } \\
\text { Dünya }\end{array}$ & 11 & 6 & 8 & 2 & 3 \\
\hline & Yolculuk & 1 & 2 & 0 & 2 & 1 \\
\hline & Toplam & 51 & 23 & 18 & 9 & 10 \\
\hline
\end{tabular}


Tablo 3'te Türkçe eğitimi, Türk dili ve edebiyatı eğitimi, sosyal bilgiler, coğrafya ve tarih bölümlerindeki öğretmen adaylarının oluşturdukları metaforlara ait çözümlenen ana temalar ve alt kategorilere yer verilmiştir. $\mathrm{Bu}$ kategoriler ayrıntılı bir şekilde Grafik 1'de yer almaktadır.

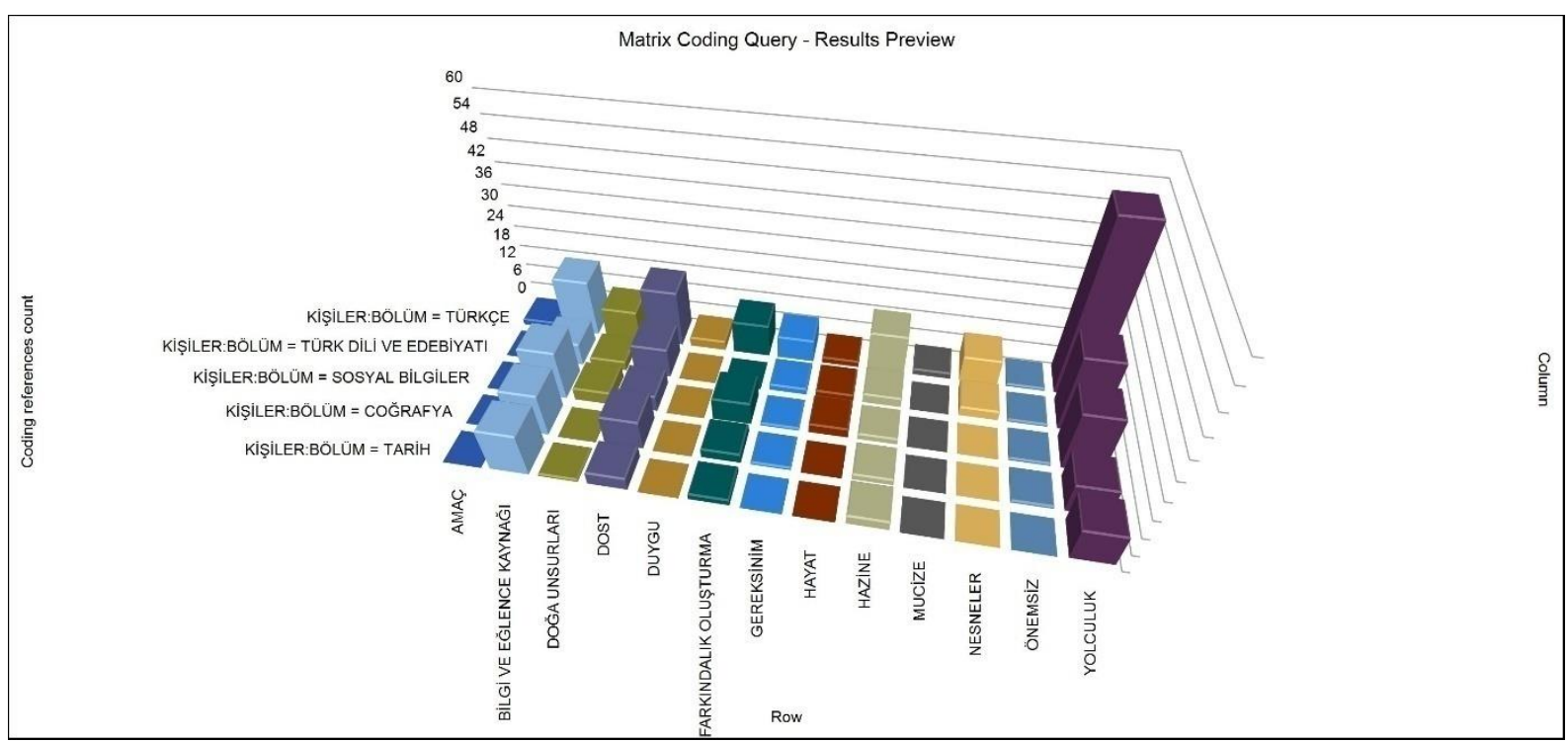

Grafik 1. Farklı Bölümlerdeki Öğretmen Adaylarının “Kitap” Kavramı Üzerine Algıları

Grafik 1 incelendiğinde, kitapla ilgili oluşturulan metaforlar 13 farklı temada toplanmıştır. Oluşturulan bu 13 temada yer alan metafor sayılarına göre;

Türkçe öğretmenliği bölümünde yer alan temalardaki metaforlar sırasıyla yolculuk (51), dost (37), bilgi ve eğlence kaynağı (17), hazine (12), farkındalık oluşturma (10), doğa (9), nesne (8), gereksinim (7), duygu (3), hayat (2), amaç (2), mucize (2) ve önemsiz (1) şeklinde sıralanmaktadır. Her alt temada bir metaforun mutlaka yer aldığ 1 görülmüş ve alt temalar içinde en çok "yolculuk” temasında metafor oluşturulduğu saptanmıştır.

Türk dili ve edebiyatı öğretmenliği bölümündeki öğretmen adaylarının oluşturduğu metaforlar yolculuk (23), dost (9), bilgi ve eğlence kaynağ1 (7), hazine (3), doğa (3), nesne (3), gereksinim (2), hayat (2), önemsiz (1) şeklinde sıralanmaktadır. Duygu, amaç, mucize ve farkındalık oluşturma temalarında metafor oluşturulmamıştır.

Sosyal bilgiler öğretmenliği bölümündeki öğretmen adaylarının oluşturduğu metaforlar sırasıyla yolculuk (18), bilgi ve eğlence kaynağı (7), farkındalık oluşturma (7), dost (5), doğa (5), hayat (3), hazine (2), önemsiz (1), gereksinim (1) şeklindedir. Duygu, nesne kitap, amaç, mucize temalarında metafor oluşturulmadığı görülmüştür.

Coğrafya öğretmenliği incelendiğinde bilgi ve eğlence kaynağı (13), yolculuk (9), dost (9), farkındalık oluşturma (3), gereksinim (1), önemsiz (1) şeklindedir. Duygu, amaç, hazine, mucize, nesne, hayat, doğa temalarında metafora rastlanmamıştır.

Tarih bölümünde yer alan temalardaki metafor sayıları ise sıra ile bilgi ve eğlence kaynağı (13), yolculuk (10), dost (4), hazine (3), farkındalık oluşturma (2) ve doğa (1) şeklinde dağılmaktadır. Nesne, gereksinim, hayat, duygu, amaç, mucize ve önemsiz temalarında ise metafor oluşturulmamıştır.

Bulguları destekleyici ve açıklayıcı olması için katılımcıların oluşturduğu metaforlardan birkaç örnek verilebilir:

"Yolculuk" temas1:

“yeni bir yola çıkmak gibi” K251, Tarih B.

“yeni bir serüven” K6, Tarih B.

\section{“Bilgi ve Eğlence Kaynağı” teması:}

“içinde yeni bilgiler barındıran bir araç” K160, TDE B. 
“eğlence aracı" K176, TDE B.

"Dost" temas:

“yalnızlı̆̆ unutturan bir dost, arkadaş" K139, Türkçe B.

“dost, arkadaş" K190, TDE B.

"Önemsiz" teması:

“Önemsiz bir araç”K157, TDE B.

“Önemsiz, vazgeçilebilir bir araçtır” K260, Coğ. B.

\section{Farklı Sınıflardaki Öğretmen Adaylarının "Kitap” Kavramı Üzerine Algılarının İncelenmesi}

Farklı sınıflardaki öğretmen adaylarının "kitap" kavramı üzerine algıları ve oluşturulan temalara göre dağılımı Tablo 4'te verilmiştir.

Tablo 4. Farklı Sınıflardaki Öğretmen Adaylarının "Kitap" Kavramı Üzerine Algıları

\begin{tabular}{|c|c|c|c|}
\hline \multicolumn{2}{|l|}{ Temalar\Sınıflar } & 1. & 4. \\
\hline \multicolumn{2}{|l|}{ Amaç } & 0 & 2 \\
\hline \multicolumn{2}{|c|}{ Bilgi ve Eğlence Kaynağ } & 22 & 43 \\
\hline \multirow{5}{*}{ Doğa } & Bitki & 3 & 1 \\
\hline & Deniz & 2 & 1 \\
\hline & Gökyüzü & 1 & 7 \\
\hline & Oksijen & 0 & 2 \\
\hline & Toplam & 6 & 11 \\
\hline \multicolumn{2}{|l|}{ Dost } & 18 & 26 \\
\hline \multicolumn{2}{|l|}{ Duygu } & 1 & 2 \\
\hline \multirow[t]{3}{*}{ Farkındalık Oluşturma } & Aydınlanmak & 6 & 16 \\
\hline & Farklı Bakış Açısı & 1 & 3 \\
\hline & Toplam & 5 & 13 \\
\hline \multicolumn{2}{|l|}{ Gereksinim } & 2 & 9 \\
\hline \multicolumn{2}{|l|}{ Yaşam } & 5 & 2 \\
\hline \multicolumn{2}{|l|}{ Hazine } & 13 & 9 \\
\hline \multicolumn{2}{|l|}{ Mucize } & 0 & 2 \\
\hline \multirow{7}{*}{ Nesneler } & Ayna & 3 & 0 \\
\hline & İlaç & 1 & 2 \\
\hline & Karakutu & 1 & 0 \\
\hline & Keyif Verici Madde & 2 & 0 \\
\hline & Özel Makine & 0 & 2 \\
\hline & & 7 & 4 \\
\hline & Toplam & & \\
\hline \multicolumn{2}{|l|}{ Onemsiz } & 4 & 0 \\
\hline & Anahtar & 2 & 6 \\
\hline & Bilet & 1 & 0 \\
\hline \multirow{5}{*}{ Journey } & Dürbün & 1 & 0 \\
\hline & Fener & 2 & 0 \\
\hline & Fotoğraf & 0 & 1 \\
\hline & Kaçış & 4 & 4 \\
\hline & Kap1 & 2 & 7 \\
\hline
\end{tabular}




$\begin{array}{lcc}\text { Köprü } & 2 & 5 \\ \text { Liman } & 0 & 5 \\ \text { Merdiven } & 1 & 0 \\ \text { Pencere } & 2 & 0 \\ \text { Rehber } & 6 & 10 \\ \text { Ulaşım Aracı } & 6 & 8 \\ \text { Yeni Farklı Dünya } & 18 & 12 \\ \text { Yolculuk } & 5 & 1 \\ \text { Toplam } & 52 & 59\end{array}$

Tablo 4'te birinci sınıfta ve dördüncü sınıftaki öğretmen adaylarının oluşturdukları metaforlara ait çözümlenen ana temalar ve alt kategorilere yer verilmiştir. Bu kategoriler ayrıntılı bir şekilde Grafik 2'de yer almaktadır.

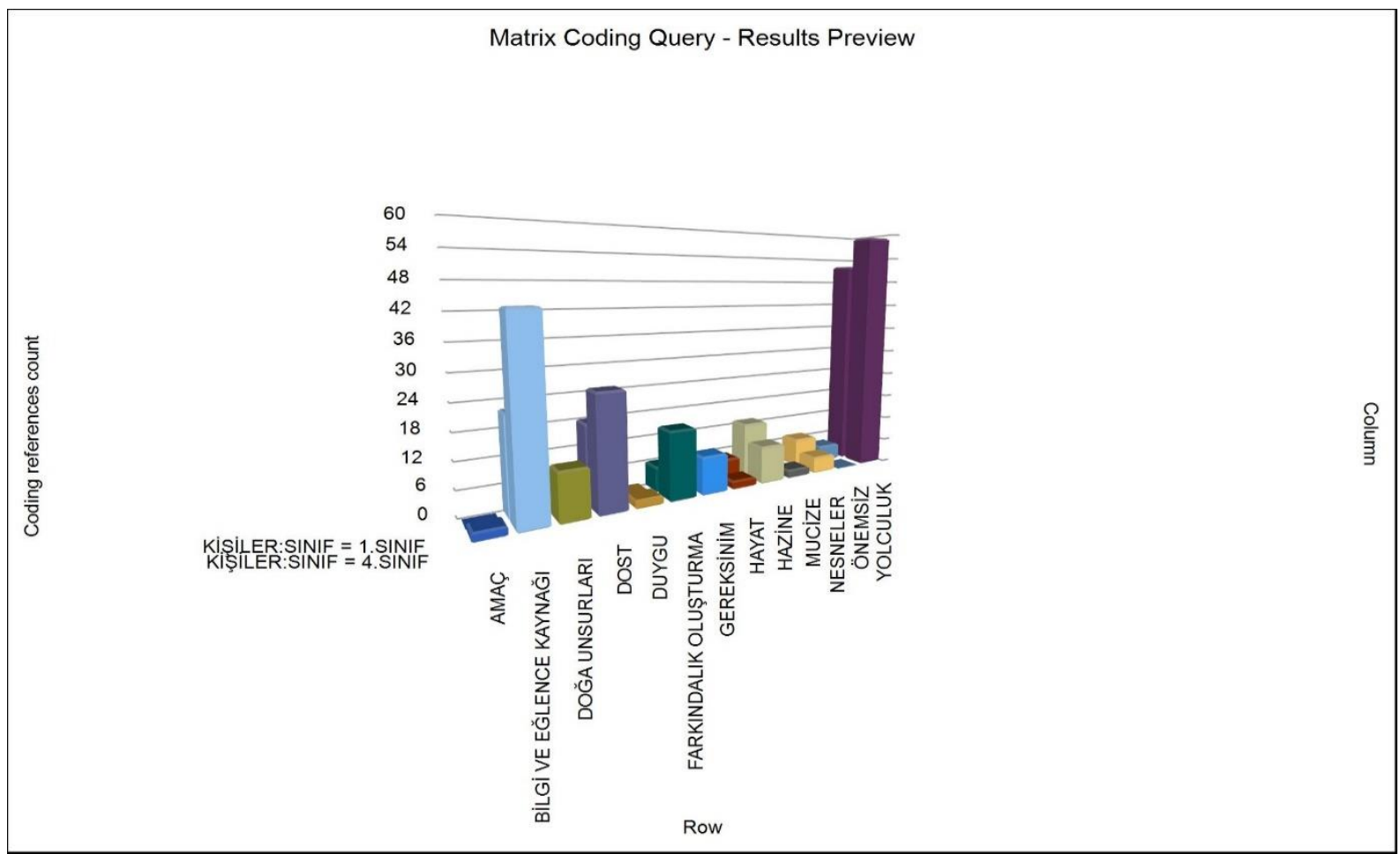

Grafik 2. Farklı Sınıflardaki Öğretmen Adaylarının "Kitap” Kavramı Üzerine Algıları

Grafik 2 incelendiğinde, kitapla ilgili oluşturulan metaforların 13 farklı tema altında birinci ve dördüncü sınıflardaki dağılımı görülmektedir. Oluşturulan bu 13 temada yer alan metafor sayıları birinci sınıflarda yolculuk (52), bilgi ve eğlence kaynağı (22), dost (18), hazine (13), nesne (7), doğa (6), farkındalık oluşturma (5), hayat (5), önemsiz (4), gereksinim (2) ve duygu (1) şeklinde sıralanmaktadır. Birinci sınıflardaki öğretmen adayları amaç ve mucize temalarında metafor oluşturmamıştır.

Dördüncü sınıflardaki öğretmen adaylarının oluşturduğu metaforlar ise sırasıyla yolculuk (59), bilgi ve eğlence kaynağı (43), dost (26), farkındalık oluşturma (13), doğa (11), hazine (9), gereksinim (9), nesne (4), hayat (2), duygu (2), amaç (2) ve mucize (2) şeklindedir. Dördüncü sınıflardaki öğretmen adaylarının hiçbiri "önemsiz" temasında metafor oluşturmamıștır.

Bulguları destekleyici ve açıklayıcı olması için katılımcıların oluşturduğu metaforlardan birkaç örnek verilebilir: 
"Yolculuk" temas1:

“sürekli farklı bilgiler katmaya devam eden sonsuzluğa giden bir yolculuğun gemisi” K144, 1.Sınıf.

“dünyanın en güzel karavanıdır” K101, 4.Sınıf

"Bilgi ve Ĕ̆lence Kaynağı” teması:

"ruhu dinlendiren bir araç” K136, 4.sınıf

“eğlenme aracı" K258, 1.sinıf

"Dost" temas1:

“yalnız kaldığımızda gizli bir dost” K2, 1.sınıf

“her zaman yanında olan dost” K323, 4.sinif

“Önemsiz" temas1:

“Önemsiz bir araç”K157, 1.Sınıf

“Önemsiz, vazgeçilebilir bir araçtır” K260, 1.sınıf

\section{Farklı Cinsiyetteki Öğretmen Adaylarının "Kitap” Kavramı Üzerine Algılarının İncelenmesi}

Farklı cinsiyetteki öğretmen adaylarının "kitap” kavramı üzerine algıları ve oluşturulan temalara göre dağılımı Tablo 5'te verilmiştir.

Tablo 5. Farklı Cinsiyetteki Öğretmen Adaylarının “Kitap” Kavramı Üzerine Algıları

\begin{tabular}{|c|c|c|c|}
\hline \multicolumn{2}{|l|}{ Temalar/Cinsiyet } & Kadın & Erkek \\
\hline \multicolumn{2}{|l|}{ Amaç } & 1 & 1 \\
\hline \multicolumn{2}{|l|}{ Bilgi ve Eğlence Kaynağ1 } & 35 & 30 \\
\hline \multirow{5}{*}{ Doğa } & Bitki & 4 & 0 \\
\hline & Deniz & 1 & 2 \\
\hline & Gökyüzü & 4 & 4 \\
\hline & Oksijen & 1 & 1 \\
\hline & Toplam & 10 & 7 \\
\hline \multicolumn{2}{|l|}{ Dost } & 27 & 17 \\
\hline \multicolumn{2}{|l|}{ Duygu } & 1 & 2 \\
\hline & Aydınlanmak & 2 & 2 \\
\hline \multirow[t]{2}{*}{ Farkındalık Oluşturma } & Fark1l BakışAçısı & 9 & 9 \\
\hline & Toplam & 11 & 11 \\
\hline \multicolumn{2}{|l|}{ Gereksinim } & 4 & 7 \\
\hline \multicolumn{2}{|l|}{ Yaşam } & 4 & 3 \\
\hline \multicolumn{2}{|l|}{ Hazine } & 12 & 10 \\
\hline \multirow[t]{4}{*}{ Mucize } & & 2 & 0 \\
\hline & Ayna & 3 & 0 \\
\hline & İlaç & 2 & 1 \\
\hline & Karakutu & 0 & 1 \\
\hline
\end{tabular}




\begin{tabular}{|c|c|c|c|}
\hline \multirow{3}{*}{ Nesneler } & Keyif Verici Madde & 0 & 2 \\
\hline & Özel Makine & 0 & 2 \\
\hline & Toplam & 5 & 6 \\
\hline \multirow[t]{17}{*}{ Önemsiz } & & 1 & 3 \\
\hline & Anahtar & 4 & 4 \\
\hline & Bilet & 0 & 1 \\
\hline & Dürbün & 1 & 0 \\
\hline & Fener & 1 & 1 \\
\hline & Fotoğraf & 1 & 0 \\
\hline & Kaçış & 7 & 1 \\
\hline & Kap1 & 6 & 3 \\
\hline & Köprü & 1 & 6 \\
\hline & Liman & 4 & 1 \\
\hline & Merdiven & 0 & 1 \\
\hline & Pencere & 2 & 0 \\
\hline & Rehber & 7 & 9 \\
\hline & Ulaşım Aracı & 12 & 2 \\
\hline & Yeni Farklı Dünya & 19 & 11 \\
\hline & Yolculuk & 4 & 2 \\
\hline & Toplam & 69 & 42 \\
\hline
\end{tabular}

Tablo 5'te kadın ve erkek öğretmen adaylarının oluşturdukları metaforlara ait çözümlenen ana temalar ve alt kategorilere yer verilmiştir. Bu kategoriler ayrıntılı bir şekilde Grafik 3’te yer almaktadır.

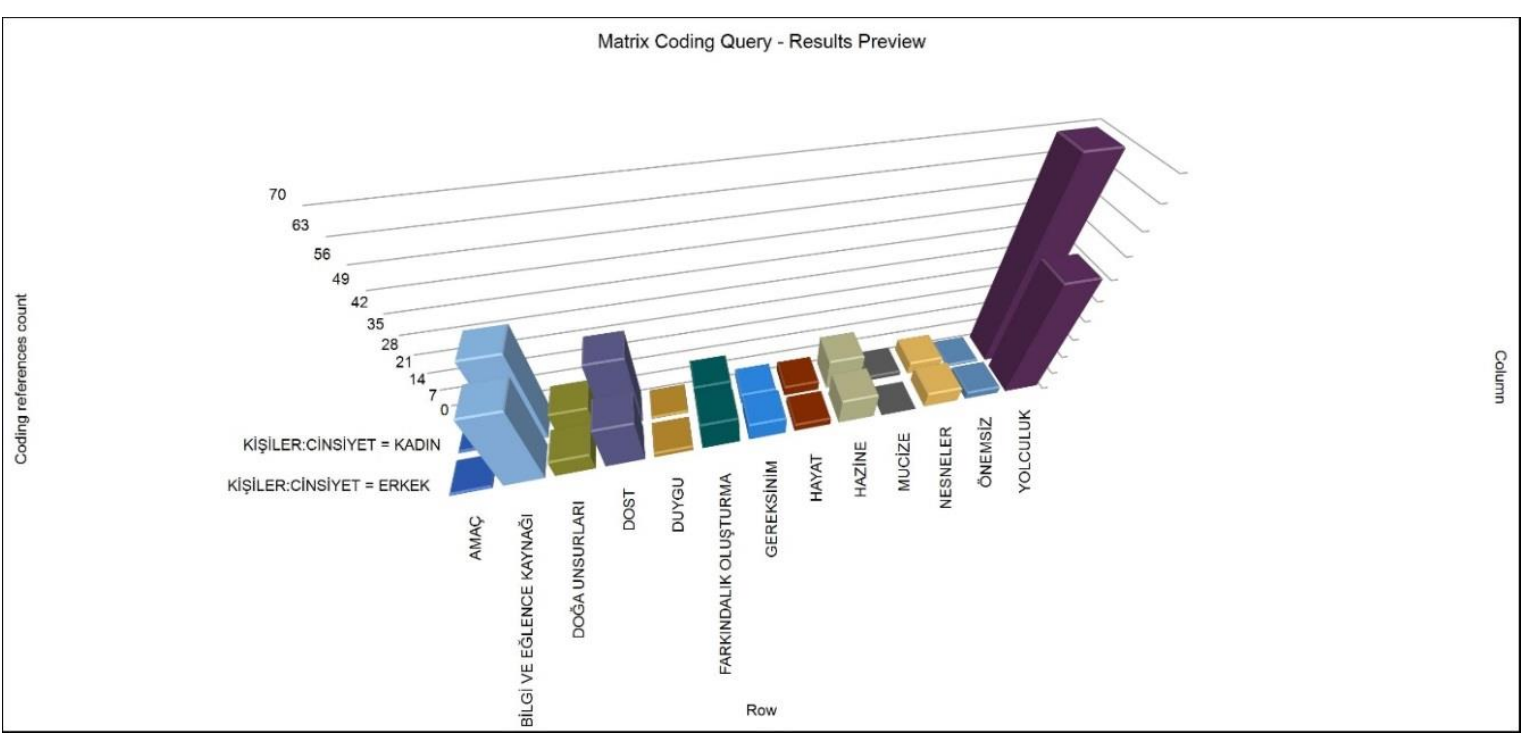

Grafik 3: Farklı Cinsiyetlerdeki Öğretmen Adaylarının “Kitap” Kavramı Üzerine Algıları

Grafik 3 incelendiğinde, kitapla ilgili oluşturulan metaforlar 13 farklı temanın kadın ve erkek öğretmen adaylarındaki dağılımı görülmektedir. Oluşturulan bu 13 temada yer alan metafor sayıları kadınlarda sırasıyla 
yolculuk (69), bilgi ve eğlence kaynağı (35), dost (27), hazine (12), farkındalık oluşturma (11), doğa (10), nesne (5), gereksinim (4), hayat (4), mucize (2), önemsiz (1), duygu (1) ve amaç (1) şeklindedir.

Erkeklerde ise sırasıyla yolculuk (42), bilgi ve eğlence kaynağ 1 (30), dost (17), farkındalık oluşturma (11), hazine (10), doğa (7), gereksinim (7), nesne (6), hayat (3), önemsiz (3), duygu (2) ve amaç (1) şeklindedir. Mucize temasında ise metafor oluşturulmamıştır.

Bulguları destekleyici ve açıklayıcı olması için katılımcıların oluşturduğu metaforlardan birkaç örnek verilebilir:

"Yolculuk" temas1:

“yeni bir yola çıkmak gibi” K251, Kadın.

"yolculuk aracıdır" K14, Kadın.

"Bilgi ve Eğlence Kaynağı”" teması:

"bireyin gelişmesini sağlayan araç” K169, Erkek.

"güzel ve şahane bir araç" K217, Erkek.

"Dost" temas1:

“arkadaşımdır" K88, Erkek.

“arkadaş, sırdaş” K118, Kadın.

"Önemsiz" teması:

“cümlelerden ibaret, önemsiz” K21, Erkek.

“vakit kaybıdır” K42, Erkek.

\section{Sonuç ve Öneriler}

Türkçe ve Sosyal Bilimler Eğitimi bölümündeki öğretmen adaylarının "kitap" kavramı üzerine algılarını metaforlar yoluyla belirlemek amacıyla yapılan bu çalışmanın sonuçları çalışmanın alt amaçlarına göre sıralanarak tartışılmıştır.

Çalışma sonunda katılımcılardan elde edilen toplam 321 metafordan yolculuk (111), bilgi ve eğlence kaynağı (65), dost (44), hazine (22), farkındalık oluşturma (22), doğa (17), nesne (11), gereksinim (11), hayat (7), önemsiz (4), duygu (3), amaç (2) ve mucize (2) şeklinde 13 alt tema oluşturulmuştur. Elde edilen bulgular incelendiğinde öğretmen adaylarının kitapla ilgili en yüksek oranda "yolculuk" metaforunu kullandıkları görülmektedir. Öğretmen adaylarının çoğunluğunun kitabı bir yolculuğa benzetmesi, kitabı öğrenilecek yeni bilgilere ve yeni dünyalara bir açılım olarak görmesi yönünde yorumlanabilir.

İkinci en çok kullanılan tema ise, "bilgi ve eğlence kaynağı"dır. Öğretmen adaylarının bu algısı, öğrenme stillerinin bilgi ve eğlenceyi birleştirme yönünde olması şeklinde yorumlanabilir. Bu algı da günümüz eğitim sisteminde bir amaç olan eğlenerek öğrenme, bilgi edinmeyi eğlenceli bulma bakımından önemli bir sonuçtur.

Üçüncü en çok kullanılan tema ise "dost" temasıdır. Öğretmen adaylarının bu algısı, ilk okuldan itibaren özlü sözlerle ve çeşitli söyleyişlerle desteklenen "Kitap en iyi dosttur." "Kitap en iyi arkadaştır." söyleminin bir yansımasıdır. Kitap dendiğinde ilk akla gelen metaforlardan biri şüphesiz ki "dost”tur. Çalışmamızda öğretmen adaylarının çoğunun da benzer biçimde kitabı bir "dost" olarak gördüğü belirlenmiştir.

Genel olarak öğretmen adaylarının kitaba yönelik oluşturdukları metaforlardan oluşturulan temalardan 12 temanın olumlu, bir temanın ise olumsuz olarak kategorileştirildiği görülmektedir. Çalışmaya katılan toplam 321 öğretmen adayının 317'sinin kitaba karşı olumlu metafor geliştirdiği ve sadece 4'ünün “önemsiz” diyerek olumsuz metafor geliştirdiği görülmüştür. Bu durum öğretmen adaylarının kitaba yönelik algılarının olumlu yönde olduğunun bir göstergesidir. 
Bölümlere göre öğretmen adaylarının geliştirdikleri metafor incelendiğinde Türkçe, Türk dili ve edebiyatı ve sosyal bilgiler öğretmenliği bölümündeki öğretmen adaylarının kitapla ilgili en yüksek oranda "yolculuk" metaforunu kullandıkları görülmektedir. Coğrafya ve tarih öğretmenliği bölümlerinde ise en yüksek oranda "bilgi ve eğlence kaynağı" metaforu görülmüştür. Elde edilen sonuçlar daha detaylı bir şekilde ele alındığında coğrafya öğretmenliği bölümünde "doğa” temasına yönelik metafor geliştirilmediği dikkat çekicidir. Tarih öğretmenliği bölümü hariç her bölümden bir öğrencinin kitabı "önemsiz” olarak görmesi bir diğer sonuçtur. Geleceğin kitap okuma alışkanlığı kazanmış bireylerini yetiştirecek olan, öğrencilerine dil bilinci ve kitap sevgisini aşılayacak öğretmen adayının kitabı "önemsiz" bulması kaygı vericidir ancak bu kategorideki kişi sayısının az olması bu kaygıyı hafifleterek genel algıyı fazla etkilemeyeceği düşünülmektedir.

Sınıflara göre öğrencilerin geliştirdikleri metaforlar; birinci sınıflarda yolculuk (52), bilgi ve eğlence kaynağı (22), dost (18), hazine (13), nesne (7), doğa (6), farkındalık oluşturma (5), hayat (5), önemsiz (4), gereksinim (2) ve duygu (1) şeklinde sıralanmaktadır. Birinci sınıflardaki öğretmen adayları "amaç" ve "mucize" temalarında metafor oluşturmamiştır.

Dördüncü sınıflardaki öğretmen adaylarının oluşturduğu metaforlar ise sırasıyla yolculuk (59), bilgi ve eğlence kaynağı (43), dost (26), farkındalık oluşturma 13), doğa (11), hazine (9), gereksinim (9), nesne (4), hayat (2), duygu (2), amaç (2) ve mucize (2) şeklindedir. Dördüncü sınıflardaki öğretmen adaylarının hiçbiri "önemsiz" temasında metafor oluşturmamıştır.

Sınıf düzeylerine göre birinci ve dördüncü sınıftadaki öğrencilerin kitaba karşı tutumları bakımından karşılaştırıldığında yalnızca birinci sınıftaki öğrencilerin kitaba karşı olumsuz tutum sergilediği görülmüştür. Yalnızca birinci sınıf öğrencilerinin kitaba karlı olumsuz tutum sergilmesi önemli bir sonuçtur. Eğitim fakültelerinde hemen her dersin içeriğinde kazanım olarak okuma alışkanlığı kazanma ve kazandırma yöntemleri yer almaktadır ve bu dersler birinci sınıftan son sınıfa doğru gelindiğinde yoğunlaşmaktadır. Çalışmada elde edilen bu sonuç ile, eğitim fakültelerindeki derslerin öğretmen adaylarının kitaba karşı olumlu tutum geliştirmelerinde katkı sağladığı söylenebilir.

Cinsiyet değişkenine göre oluşturulan bu 13 temada yer alan metafor sayıları kadınlarda sırasıyla yolculuk (69), bilgi ve eğlence kaynağı (35), dost (27), hazine (12), farkındalık oluşturma (11), doğa (10), nesne (5), gereksinim (4), hayat (4), mucize (2), önemsiz (1), duygu (1) ve amaç (1) şeklindedir. Erkeklerde ise sırasıyla yolculuk (42), bilgi ve eğlence kaynağı (30), dost (17), farkındalık oluşturma (11), hazine (10), doğa (7), gereksinim (7), nesne (6), hayat (3), önemsiz (3), duygu (2) ve amaç (1) şeklindedir. Mucize temasında ise metafor oluşturulmamıştır. Kadınlar ve erkekler arasında belirgin bir farklılık olmamakla beraber en sık kullanılan metaforlar "yolculuk, bilgi-eğlence kaynağı ve dost" temasında toplanmıştır.

Sonuç olarak; kitap kavramına yönelik öğretmen adaylarının algıları; okuma sevgisi ile okuma alışkanlığının yerleştirilmesi ve geliştirilmesinde önemlidir. Çünkü eğitim, hem eğitim süreçlerinin dinamiklerini tanımlamak hem de eğitim aktörlerinin işlevlerini netleştirmek ve sınıflandırmak için metaforların önemli bir rol oynadığ bir alandır (Jensen, 2006; Magalhães ve Stoer, 2007; Patchen ve Crawford, 2011). Ayrıca Haggis'in (2004) söylediği gibi, metaforlar düşünceleri şekillendirmek için kullanılabilir. Eğitim ortamlarında metafor kullanımı öğrenmeyi farklı boyutlarda görmemizi sağlar.Bu nedenle öğretmeneğitimisürecindeözellikle anlama ve anlatma eğitimi derslerinde öğrencilerin metafor oluşturmasına dair etkinlikler yapılarak öğrencilerin düşünce dünyaları geliştirilebilir. Türkçe ve Sosyal Bilimler Eğitimi bölümünde okumakta olan öğretmen adayları ile sınırlandırılan bu çalışma gelecekte diğer bölümlerdeki öğretmen adayları ile de yapılarak zenginleştirilebilir. Öğretmen adaylarının "kitap" kavramı ile metafor oluşturması ile özgünlüğü olan bu çalışma, alanyazına katkı sağlayarak "kitap” kavramı üzerine tekrar düşünülmesi sağlanabilir.

\section{Teşekkür ve Bilgilendirme}

Bu çalışma “2017.KB.EGT.002” isim ve "201759” no ile DEU BAP birimi tarafından desteklenmiştir. 


\section{References}

Alacapınar, F. (2011). İlköğretim okulu öğrencileri “öğretmenlerini” nelere benzetmektedirler. [Who do elementary school students liken their teacher to]. Ahmet Keleşoğlu Education Faculty Journal, 32, 249-263.

Aspin, D. (1984). Metaphor and meaning in educational discourse. In W. Taylor (Ed.), Metaphors of education (pp. 21-37). London: Heinemann Educational.

Aydın, E. \& Sulak, S.E. (2015). Sınıf öğretmeni adaylarının “değer” kavramına yönelik metafor algıları. [The thoughts and metaphoric perceptions of primary school teacher candidates about value concept]. Bartın University Journal of Faculty of Education, 4(2), Doi: 10.14686/buefad.v4i2.5000148420 482-500.

Bektaş, M. \& Okur, A. \& Karadağ, B. (2014). İlkokul ve ortaokul son sınıf öğrencilerinde metaforik algı olarak kitap. [Book as a metaphoric perception in last class of the primary and secondary students]. Türk Kütüphaneciliği 28, 2 (2014), 154-168.

Cerit, Y. (2006). Öğrenci, öğretmenveyöneticilerinokulkavramıylailgilimetaforlarailişkingörüşleri. [Students, teachers and administrators' views on metaphors with respect to the concept of principal]. Educational Sciences: Theory \& Practice, 6 (3),669-699.

Çelikkaya,T. \& Seyhan, O. (2017). Sosyal bilgiler öğretmenlerinin ve öğretmen adaylarının evrensel değerlere ilişkin metafor algıları. [Metaphor perceptions of social studies teachers and preservice teachers related to universal values]. E-International Journal of Educational Research, Vol: 8, No: 3, 2017,pp.65-87, DOI: 10.19160/ijer.342330.

Döş, İ. (2010). Aday öğretmenlerin müfettişlik kavramına ilişkin metafor algıları. [Metaphoric perceptions of candidate teachers to the concept of inspectors]. Gaziantep University Social Science Journal, 9 (3), 607-629.

Ekici, G. \& Baş, M. \& Kızılkaya, O. (2017). Öğretmen adaylarının “öğretmenlik mesleği” kavramına ilişkin algılarının belirlenmesi: bir metafor analizi çalışması. [Determination of perception regarding the "teaching profession" of teacher candidates: a work of metaphor analysis]. International Journal Of Eurasia Social Sciences, Vol: 8, Issue: 28. pp. CCLXXXVIII-CCCXIII.

Güneyli, A. \& Akıntuğ, Y. (2012). Kitap kavramına ilişkin zihinsel imgeler (Yakın Doğu Üniversitesi örneği). [Metaphors regarding the concept of book (Near East University case) ]. Educational Sciences: Theory \& Practice - 12(3), 1784-1790.

Haggis, T. (2004). Constructions of learning in higher education: metaphor, epistemology, and complexity. In J. Satterthwaite \& E. Atkinson (Eds.), The disciplining of education: New languages of power and resistance (pp. 181-197). Stoke on Trent: Trentham.

Jensen, D.F.N. (2006). Metaphors as a bridge to understanding educational and social contexts. International Journal of Qualitative Methods, 5(1).

Lakoff, G. \& Johnson, M. (2005). Metaforlar, hayat, anlam ve dil. [Metaphors, life, meaning and language]. İstanbul: Paradigma Publishing.

Low, G.D. \& Littlemore, J. \& Koester, A. (2008). Metaphor use in three UK university lectures. Applied Linguistics, 29(3), 428-455.

Magalhães, A. M. \& Stoer, S. (2007). Europe as a bazar: A contribution to the analysis of the reconfiguration of Nation-States and new forms of "living together". In C. Torres \& A. Teodoro (Ed.), Critique and utopia: New developments in the sociology of education in the Twenty-First century (pp. 65-86). Maryland: Rowman \& Littlefield Publishers.

Ocak, G. \& Gündüz, M. (2006). Eğitim fakültesini yeni kazanan öğretmen adaylarının öğretmenlik mesleğine giriş dersini almadan önce ve aldıktan sonra öğretmenlik mesleği hakkındak imetaforlarının karşılaştırılması. [The comparison of pre-service teachers' metaphors about the teacher-profession before and after the introduction to teacher-profession course]. AfyonKocatepe University Social Science Journal, 8 (2):293-309.

Patchen, T. \& Crawford, T. (2011). From gardeners to tour guides: The epistemological struggle revealed in teacher-generated metaphors of teaching. Journal of Teacher Education, 62(3), 286-298. 
Saban, A. (2009). Öğretmen adaylarının öğrenci kavramına ilişkin sahip oldukları zihinsel imgeler. [Prospectıve teachers' mental images about the concept of student]. Turkish Education Science Journal.7 (2), 281-326.

Saban, A. \& Koçbeker, B. N. \& Saban, A. (2006). Öğretmen adaylarının öğretmen kavramına ilişkin algılarının metafor analizi yoluyla incelenmesi. [An investigation of the concept of teacher among prospective teachers through metaphor analysis]. Educational Sciences: Theory \&Practice, 6 (2), 461-522.

Soysal, D. \& Afacan, Ö. (2012). İlköğretim öğrencilerinin “fen ve teknoloji dersi” ve "fen ve teknoloji öğretmeni” kavramlarina yönelik metafor durumlari. [Metaphors used by primary school students to describe "science and technology lesson" and "science and technology teacher"]. Mustafa Kemal University Journal of Social Sciences, 9(19): 287-306.

Yıldırım, A. \& Şimşek, H. (2005). Sosyal bilimlerde nitel araştırma yöntemler.i [Qualitative research in social sciences]. Ankara: Seçkin Publishing. 